\title{
Volcanoes and climate: the triggering of preboreal Jökulhlaups in Iceland
}

Van Vliet-Lanoë Brigitte 1, * , Knudsen Oskar ${ }^{2}$, Guðmundsson Agust ${ }^{3}$, Guillou Hervé ${ }^{4}$, Chazot Gilles ${ }^{1}$, Langlade Jessica ${ }^{5}$, Liorzou Celine ${ }^{1}$, Nonnotte Philippe ${ }^{1}$

1 Géosciences Ocean, UMR 6538 Brest University, CNRS, ue@b, IUEM, PI.N.Copernic, 29280,

Plouzané, France

2 Klettur Consulting Engineers, Bildshofda 12, 102, Reykjavik, Iceland

3 Jarðfræðistofan ehf, 200, Hafnarfjorður, Iceland

${ }^{4}$ CNRS-CEA, UMR 8212 LSCE, Domaines CNRS, Bât. 12, Av. de la terrasse, 91198, Gif/Yvette, France

${ }^{5}$ Microsonde de l'Ouest, Ifremer-Centre de BretagneTechnopole Brest Iroise, BP 70, 29280, Plouzané, France

* Corresponding author : Brigitte Van Vliet-Lanoë, email address : brigitte.vanvlietlanoe@univ-brest.fr

\begin{abstract}
:
The Early Holocene (12-8.2 cal ka) deglaciation and pulsed warming was associated in Iceland with two major generations of jökulhlaups around the Vatna ice-cap (Vatnajökull), at ca 11.4-11.2 cal ka and ca 10.4-9.9 cal ka, and major tephra emissions from the Grímsvötn and Bárðarbunga subglacial volcanoes. The earliest flood events were recorded inland during the Middle Younger Dryas and their deposits were overlain by the Early Preboreal Vedde Ash $(11.8 \mathrm{cal} \mathrm{ka})$. The first Holocene flood events (ca 11.4$11.2 \mathrm{cal} \mathrm{ka)}$ are issued from a glacial advance. The second, and major, set of floods was partly driven by the Erdalen cold events and advances (10.1-9.7 10Be ka) initially issued from the Bárðarbunga (10.4, 10.1-9.9 ka) and Grímsvötn volcanoes (Saksunarvatn tephra complex, ca. 10.2-9.9 cal ka). These floods were also fed by the residual glacio-isostatic depressions below the Vatnajökull that enabled the storage of meltwaters in large subglacial lakes or aquifers until ca. $9.3 \mathrm{cal} \mathrm{ka}$. This storage was enhanced by icedamming and permafrost, especially during the twinned Erdalen events. Due to the glacio-isostatic rebound, the general slope was nearly flat, and the valley was partly filled with sediments until ca $10.8 \mathrm{cal} \mathrm{ka}$. Temporary lacustrine deposits in this valley resulted from the very broad splay of waters as for the ca $11.2 \mathrm{cal} \mathrm{ka}$ and ca $10.1-9.9 \mathrm{cal} \mathrm{ka}$ flood, due to regional permafrost. These floods had a potential duration of several months as they were mostly fed by climate-driven meltwater. The maximal volume evacuated by these events did not greatly exceed $1 \times 106 \mathrm{~m} 3 \mathrm{~s}-1$ from the flood-affected transverse profile of the valleys that remain partly filled with sediments.
\end{abstract}

Keywords : Holocene, Deglaciation, Iceland, Geomorphology, Glacial, Flood, Sedimentology, Tephra, Glacio-isostatic rebound, Permafrost, Saksunarvatn event, Askja S 


\section{Introduction}

Large-scale outburst flows were a common phenomenon that accompanied the termination of the last glaciation in non-volcanic regions (e.g. Carling 2013). Meltwater storage in or at the surface of a glacier favours jökulhlaup occurrence (Rushmer 2006; Carrivick et al. 2009). Jökulhlaups may be also triggered by volcanism. As volcanism and melting are enhanced by deglaciation (Jull and McKenzie, 1996; Slater et al. 1998; MacLennan et al. 2002; Sinton et al. 2005), these events are suspected having promoted both jökulhlaups and more explosive volcanism (Höskuldsson et al. 2006; Van VlietLanoë et al. 2007; Carrivick et al. 2009).

The analysis of the Early Holocene (ICS 2018) deglaciation in Iceland is a favourable place to understand their interrelations due to the radial organization of the drainage around the Vatnajökull (Fig. 1), the largest Late Holocene ice-cap.

Major active volcanic systems, with an extensive morphological impact, exist beneath the Vatnajökull (Fig. 1B) in the form of the Grímsvötn and Bárðarbunga Volcanoes (Björnsson 2017). The Vatnajökull rests on porous volcanogenic sediments on the western side of the Grímsvötn caldera, and on the impermeable bedrock below the Brúarjökull glacier and to the east (Flowers et al. 2003). Subglacial eruptions, associated with tephra outfalls from the Grímsvötn calderas, were responsible for numerous hazardous jökulhlaups to the north and south (Thorarinsson 1974; Björnsson 1992; Thordarson and Larsen 2007). The relationship between jökulhlaups and the last deglaciation is not analysed in Iceland, even though most of the terminal moraines in the south have been carefully described by Kaldal and Víkingsson (1990) and a chronology of jökulhaup events has been extracted from the lacustrine record of the deglaciation by Geirsdóttir et al. (2000).

The interval analysed in this paper covers the Younger Dryas to the Holocene Thermal Optimum (12.8 - $8 \mathrm{cal} \mathrm{ka).} \mathrm{The} \mathrm{period} \mathrm{from} \mathrm{Termination} \mathrm{Ib} \mathrm{(11.8} \mathrm{cal} \mathrm{ka,} \mathrm{ICS} \mathrm{2018)} \mathrm{to} \mathrm{the} \mathrm{Thermal} \mathrm{Optimum} \mathrm{(8-6} \mathrm{cal}$ ka) was characterised in the south of Iceland (Fig. 1a) by a series of jökulhlaups (Geirsdóttir et al. 2000). In the southernmost Iceland, the first major Early Holocene eruption after Termination Ib and the deposition of the Vedde Ash was the Saksunarvatn Tephra (Mangerud et al. 1986). This was issued from the Grímsvötn Volcano at ca. $10.28 \mathrm{cal} \mathrm{ka} \mathrm{BP} \mathrm{(Tephrabase),} \mathrm{and} \mathrm{was} \mathrm{a} \mathrm{potential} \mathrm{trigger} \mathrm{of}$ major jökulhlaups. This volcano generated a large jökulhlaup via the Skeiðarárjökull Glacier (Fig.1B), 
which delivered turbidites to the Mýrdalsjökull Submarine Canyon at ca 10.15 cal ka (Fig.1B, Lacasse et al. 1998). The source of the largest Holocene jökulhlaup events in the north is commonly attributed to the Grímsvötn and Kverkfjöll calderas (Sæmundsson 1973; Carrivick 2007; Carrivick et al. 2009) with another source in the Bárðarbunga subglacial caldera (Björnsson and Einarsson 1991; Waitt 2002; Fig. 1A, 2, 3A). These volcanoes were also responsible for jökulhlaups during the Eemian and the Holocene in the south, e.g. along the Jökulsá á Fjöllum and Pjorsá-Ytrí Rangá Rivers (Van VlietLanoë et al. 2018).

In the North, most studies up to now have been focused on the main channel of the Jökulsá á Fjöllum (Fig.1a) and its morphologies (e.g. Middle Holocene floods: Kirkbride et al. 2006; synthesis in Baynes et al. 2015), but little attention has been paid to traces existing outside the canyon, especially on the nearby plateau, or upstream of adjacent dry valleys. This valley experienced multiple jökulhlaups of varying sizes following Termination $\mathrm{lb}$, as evidenced by a sequence of prehistoric flood deposits in the river canyon (e.g. Björnsson and Kristmannsdóttir, 1984) and on the upper terraces (this paper).

In this paper, we attempt to synthesize the existing published data, complemented with new observations that constrain the timing of the Holocene deglaciation and the early jökulhlaup events. It will be related to the Preboreal glacial advances and retreats, and their respective dynamic conditions. We first searched for key sedimentary sections with available chronological markers constraining intime as tephra the deglaciation history inland and on the continental shelf. The gathered data, including the permafrost information, was correlated with the climatic framework of the Early Holocene. Following this, we have tried to constrain the impact of the Early Holocene deglaciation on the Vatnajökull hydrological system and jökulhlaup recurrences. Control of glacio-isostasy and its impact on the volcanism was analysed, with a special focus on the complex Saksunarvatn tephra.

\section{Methodology}

Most of this work was performed on digital satellite images and aerial photos black and white and colour provided mostly by Landmælingar Íslands (National Land Survey of Iceland) and occasionally Google Earth (GE) for various dates, complemented by the photographic interpretations of Kaldal and Vikingsson (1990), Sæmundsson et al. (2012) and Sigurgeirsson et al. (2015). In terms of glaciation, 
attention was primarily paid to fluted morphologies, "pitted" or hummocky moraines, surge moraines and normal terminal moraines (Fig. 1B), in an attempt to place them within a chronological framework. The development of specific periglacial morphologies (pattern grounds, rock glaciers) was used to delimit the glacier boundaries (Guomundsson 2000). Erosional and sedimentary morphologies induced by flood activities (e.g. Maizel 2009; Baynes et al. 2015) were analysed using the same images as for the glacial morphology: channeled scablands with scourings, canyons and plunge basins, dry perched valleys, dismantled surfaces of lava flows, potholes, pillars and rough surfaces on consolidated sediments, streamlined residual landforms, fluviatile dunes. These morphologies were used to map the maximal flood extent (Fig. 1A).

The tephra record used herein (Table 1) refers to the published data from Icelandic lakes and soils, and the marine- and ice-core records (Greenland and Iceland shelf; Wohlfarth et al. 2006; Koren et al. 2008; Lind and Wastegård 2011; Óladóttir et al. 2011; Larsen et al. 2012; Voelker and Haflidason 2015; Guðmundsdóttir et al. 2016). Tephra and sediments were analysed in bulk by ICP-MS AES to determine their sources, with single-grain microprobe and laser ICP-MS being used to determine the source of rhyolitic tephra. Tephra-derived ages are given in c. X cal ka (BP), to avoid repetition of error margins, most of them being established on age models.

\section{Paleoclimate and volcanic context}

\subsection{Deglaciation context and climate}

The onset of the Younger Dryas (YD, $12.9 \mathrm{cal} \mathrm{ka}$ ) was driven both by Oceanic circulation perturbation (Condron and Winsor 2012) and by a major solar minimum (Andresen et al. 2000; Goslar et al 2000). Since the YD, the Northern Hemisphere deglaciation has proceeded with brief, discrete cooling events, at c. 11.3-11.1 cal ka , 10.3, 9.3 and 8.2 cal ka (Fig.3), associated with the advance of glaciers (North Greenland Ice Core Project [NGRIP], 2004). Four episodes of glacier advance fit the cooling events thatbeen recognised in the ocean (Bond et al. 2001), in Scandinavia, the Færoe Islands and Greenland (Rasmussen et al. 2006; Matthews et al. 2008; Geirsdóttir et al. 2009; Kobashi et al. 2017): the Preboreal oscillation (11.3-11.1 cal ka; the 10.3-10.2 cal ka / 10.1-9.7 ${ }^{10} \mathrm{Be}$ ka cooling or Erdalen cooling events (Fig.3) allegedly driven by volcanic activity (Linde and Wastergård, 2011; Rasmussen et al. 2014) and a c. 9.3 cal ka cooling linked to a solar low that lasted for over 50 years $\left({ }^{10} \mathrm{Be}\right.$; Björck 
et al. 1997; Bos et al. 2007). The youngest, the classical " 8.2 cal ka" cooling event was the longest and coolest lasting for the next two to four centuries (Matero et al. 2017). This cooling seems triggered by solar activity (Stuiver and Braziunas 1988; Bond et al. 2001; Vonmoos et al. 2006), by a major meltwater pulse, issued from the Laurentide Ice Sheet collapse (Matero et al. 2017) with some impact of volcanic activity (Kobashi et al. 2017).

The Early Holocene pulsed warming was associated with the restoration of the North Atlantic and Irminger Currents, which increased the temperature and precipitation resulting in an accelerated icesheet retreat in Iceland (Jennings et al. 2000). The main Icelandic ice-sheet retreated rapidly across the highlands at that time (Geirsdóttir et al. 2009). After the "8.2 cal ka" cooling, the glaciers almost disappeared in Iceland. The thermal optimum was apparently ca. $2^{\circ} \mathrm{C}-3^{\circ} \mathrm{C}$ higher than today (Andresen et al. 2007; Geirsdóttir et al. 2009; Langdon et al. 2010).

The Younger Dryas cooling has a duration of 1 ka (Condron and Winsor 2012), long enough for promoting glacier advances as demonstrated for the North by the ${ }^{36} \mathrm{Cl}$ dating of rockglaciers and coastal deposits (Andrès et al. 2016; Andrès et al. 2019), but not for restoring the ice-sheet, as has been commonly proposed (Norðdhal and Petursson, 2005; Patton et al. 2015) on the base of radiocarbon dated coastal deposits. This restricted extent is demonstrated in the west of the island by the limited glacioisosatic rebound of the YD (Brader et al. 2015). The YD seems to have been associated with the spreading of ice-lobes in the south (Geirsdóttir et al. 2009; Van Vliet-Lanoë et al. 2018) although the tidal glacier or ice-streams, calving into the coastal bays, occupied the valleys in the west and the north (Fig. 1; Jennings et al. 2007; Geirsdóttir et al. 2009; Andrès et al. 2019).

The durations of the pulsed Holocene cooling events were relatively short, with ca 150 years for the "10.3 cal ka" twinned events, 50 to 200 years for the "9.3 cal ka" event and 200 to 400 years for the "8.2 cal ka" event (Rasmussen et al. 2006; Matero et al. 2017). They are considered to have been insufficient to have favoured ice-sheet development or major valley glacier advances during the Holocene. However, they were sufficient enough to have promoted glacier surges (Meier and Post, 1969).

\subsection{Glaciers and permafrost}

\subsection{Subglacial volcanoes}


The Grímsvötn volcanic system is believed to have been the most active volcano during the Holocene (Björnsson 1974; Larsen et al. 1998; Óladóttir et al. 2011), with an eruption frequency quite constant through time, and higher activity cycles, 60 to 80 years long. This volcano appears to have two reservoirs - a deeper one at $15 \mathrm{~km}$ depth and a shallow one at $3 \mathrm{~km}$ depth (Reverso et al. 2014) probably very reactive to deglaciation events via unloading (Hoskuldsson et al. 2006). Its large calderas, $3.6 \mathrm{~km}^{3}$ in volume, is a major zone of meltwater storage, and a source for jökulhlaups, especially along the southern coast (Björnsson 2002). The detailed geochemistry of the Grímsvötn eruptions (single-grain laser ICP-MS) is not suitable for dating, as very few variations were recorded during the Holocene (Oladóttir et al. 2014; Thordarson 2014).

The Bárðarbunga Volcano, located at the NW edge of Vatnajökull, forms a wide and elevated caldera (1850 masl), completely glacier covered and is located along the extensive Veiðivötn fissure system, which parallels the Grímsvötn fissure system. The reservoir is located at a depth of $12 \mathrm{~km}$ (Guormundsson et al. 2016). During the Holocene, the eruption frequency was five eruptions per century (Óladóttir et al. 2011). Its wide caldera, $14.4 \mathrm{~km}^{3}$ in volume, has been a major source for jökulhlaups, especially in the southern embayment (Björnsson 2002). The Bárðarbunga Volcano had probably already been emerging from the ice-sheet since Bölling times, based on the tephra record (Table 1), producing five significant eruptions, at c.11.35, $11-10.8,10.4,10.1$ and 9.9 cal ka (Óladóttir et al. 2011). .

\subsection{The Askja rhyolitic tephra}

Questions exist in the literature concerning the Askja 10/S Tephra, first described in Iceland and observed in Eyafjördur above the Vedde Ash (Sigurðsson and Sparks 1978; Askja 10) and below the Reitsvik 8 Tephra (c.10.2 cal ka; Larsen et al. 2002; Guðmundstottir et al. 2016). The classic Askja S Tephra age is now $10.8 \mathrm{cal}$ ka (Wolfarth et al. 2006; Bronk et al. 2015; Table 1). In the Early Holocene, the Askja Volcano emitted probably at least five rhyolitic tephra, at c. 9.4 cal ka, c. 10.4 cal ka (10.5 10.35 cal ka; Lind and Wastegård 2011), 10.8 cal ka (Askja S), c. 11.5 cal ka (Ott et al. 2016), and c. 12.5 and 12.9 cal ka (Jones et al. 2017). The Krapla 10 Tephra (Sæmundsson et al. 2012), very likely equates to the Reitsvík 8 Tephra (10.2 cal ka; Guðmundsdóttir et al. 2016), based on the available geochemical analysis (Krafla Phase 3; Jonásson 1994) but is hard to distinguish. 


\subsection{The Saksunarvatn basaltic tephra}

199 The most common and thick tephra during the deglaciation is the Saksunarvatn Tephra (ca. 10.3 cal ka; Mangerud et al. 1986; Fig.3). Dates for this very large deposit (>15 km³) cover several eruptive events. In the Icelandic lake cores, there are up to six Early Holocene tephra layers with a Grímsvötn chemical composition (Jóhannsdóttir, 2007; Fig.2A). The Saksunarvatn Tephra has not been recorded in the Jökulsà à Fjöllum, although it is present in the Eyafjördur Fjord (Fig.1A; Larsen and Eiríksson, 2007) and on the northern shelf (Eiríksson et al. 2000). In Iceland and Norway (Guðmundsdóttir et al. 2016; Andresen et al. 2007; Birks et al. 1996; Grönvold et al. 1995; Fig 1a), Saksunarvatn/Grímsvötntype ash sedimentation began at c. $10.24 \mathrm{cal}$ ka and continued up to $9.9 \mathrm{cal}$ ka. In marine cores, four aerial Grímsvötn eruptions were recorded from 10.30 to $9.85 \mathrm{cal}$ ka (marine age-model; Lacasse et al. 1998; Guðmundsdóttir et al. 2012; Voelker and Haflidason 2015). In Greenland ice cores, the ranges are from 10.24 - 10.12 ka ice-core ka (Rasmussen et al. 2006). It thus seems that the major Grímsvötn eruption took place at ca $10.24 \mathrm{cal}$ ka, followed by serial eruptions until $10.12 \mathrm{cal}$ ka. The Mýrdal Canyon turbidite, identified in the south $(10.15 \mathrm{cal} \mathrm{ka})$ possibly corresponded to a large subglacial flood.

\subsection{Holocene and historical jökulhlaups}

The Jökulsá á Fjöllum River is incised by many dry channels issued from jökulhlaups, mapped by Sæmundsson et al. 2012). Most of the studies were conducted along the canyon. From 1600 until 1934 AD, one large jökulhlaup per decade was issued from the Grímsvötn volcanic system into the Jökulsá á Fjöllum River (Björnsson and Kristmannsdóttir 1984), fitting more or less with the basic decennial frequency of eruptions (Óladóttir et al. 2011). Some Holocene events have been detected in the same river between 7.10 and 2.0 cal ka (Sæmundsson 1973; Tómasson 1973; Elíasson 1977; Waitt 2002; Kirkbride et al. 2006; Baynes et al. 2015), and specifically at c.. 4.6 cal ka, 3 cal ka and 2 cal ka. In the SW, the main jökulhlaup activities have been assigned to $12.0-11.2 \mathrm{cal}$ ka and c. $10.3-9.9$ cal ka, essentially from Hestvatn Lake stratigraphy (Geirsdóttir et al. 2000). In the east of this sector (Pjórsá-Tungnaá river system), we have previously shown that, from 155 to $8 \mathrm{ka}$, most of the jökulhlaups were issued from both the volcanoes (Van Vliet-Lanoë et al. 2018). 
Historical jökulhlaups have also been analysed near the southern edge of the Vatnajökull, particularly in relation to the Skeiðarárjökull Glacier (southern Vatnajökull; Maizels, 1991, 1997; Snorrasson et al. 1997; Russell et al. 2001).

\section{Results}

\subsection{Tephrostratigraphy}

Tephrostratigraphy and geochemistry were used to clarify regionally the age attributions of different events observed on aerial photography and controlled in the field. All the geochemical data are shown in Table 2.

Askja $S$ is the most frequently recorded tephra of the observed series (see also Supplement, Figs. 3, 4).The observed Askja S Tephra seems to be a mixture of rhyolitic and dacitic lavas, whilst the Askja $E$ rhyolite is mixed with basaltic components that were issued from the Askja/Bárðarbunga and Torfa Volcanoes (Supplement Table 2).

We proposed the following nomenclature to simplify the reading in time of the observed tephra: the Askja E tephra, at ca $10.4 \mathrm{cal} \mathrm{ka}$ and the Askja S, corresponding to the classical ca $10.8 \mathrm{cal}$ ka tephra, both predate the Erdalen Event; the Vedde Ash (11,8 cal ka) and the Askja PB tephra at ca $11.5 \mathrm{cal}$ ka predate most of the Preboreal events; the Askja YD tephra at ca 12.5 and 12.9 cal ka related to the YD events were not observed in sections in the 4 investigated Vatnajökull outlets systems.

\subsection{The Jökulsá á Fjöllum system (Fig.2B)}

The Röndin coastal section records the whole Late Glacial, followed by the transgression of the Termination Ib (from radiocarbon analysis; Norðdhal and Pétursson, 2005). These deposits lap onto local Eemian deposits (Van Vliet-Lanoë et al. 2005). The canyon of the Jökulsá á Fjöllum River (Supplement Fig. 2) seems to be ancient (Sæmundsson, 1973; Wait, 2002) and was filled with ca. 100 $\mathrm{m}$ of lithified glaciofluvial and lacustrine sediments, overlaid by Saalian and Eemian deposits, forming a progradation in a pre-existing incision. These Eemian deposits crop out at several places in the valley Van Vliet-Lanoë et al. 2001, 2005; Fig. 2B- yellow stars; Supplement Fig. 2). 


\subsubsection{Left bank - Asbyrgi, Vestudalur and Hnausar}

This sector has been classically analysed along the canyon from a morphological point of view (see $\S$ 3.6). Near the Asbyrgi dead-end, commonly attributed to prehistorical events, on the left bank, large flood evidence exists outside the canyon, in the form of vegetated fluviatile megaripple fields (west of the Klappir terrace; Fig. 4), at 170 and 202 masl, with a train of smaller megaripples (east of Lambafell; Fig. 4).

In continuation of Asbyrgi / Klappir main terrace, the Vesturdalur one and the canyon are occupied by the Hljóðaklettar sublacustrine rootless basalt injections (Vesturdalur site, left bank; Hjartardóttir and Einarsson, 2017) estimated to be c. $10.8 \mathrm{ka}$ in age, based on the Askja S Tephra analyses (Sigurgeirsson, 2016). They form a lava lake on the rocky valley bottom, close to the present river level, at an altitude of $145-150$ masl (Fig. 2B; Supplement Fig. 3). The terrace on the left bank is topped at a 191 masl altitude by ca. $5 \mathrm{~m}$ of black tephra deposits and rootless cones with an Askja/Bárðarbunga geochemical signature (Table 2, sample Vest D2, see Supplement for pictures). This tephra being older than the overlying Askja E Tephra (10.4 cal ka; Table 2: Vest D3; Supplement Fig.3), seems to be local (lapilli from the rootless cones) but also associated with the Askja S Tephra (10.8 cal ka). On the other side of the valley, the fissural eruption feeding the Hljóðaklettar system consists of aerial cinder cones on the highest terrace, at 325 -350 masl, partly eroded by jökulhlaups. It issued from the Askja Volcanic system, and is subsynchronous with the Askja S Tephra (10.8 cal ka; Sigurgeirsson, 2016).

At the Hnausar site (Figs 2b-c, 4), $5 \mathrm{~km}$ south of Vestudalur site, new observations in quarries and roadworks have revealed jökulhlaup deposits perched high, at 392 masl, in a juxtaglacial position (kame terrace at 396 masl. These deposits are covered by three tephra in loesses: a Barðabunga basaltic tephra, a rhyolitic Vedde Ash (c. $11.8 \mathrm{cal} \mathrm{ka)} \mathrm{(Table} \mathrm{2),} \mathrm{and} \mathrm{a} \mathrm{thin} \mathrm{Askja} \mathrm{tephra,} \mathrm{probably} \mathrm{PB}$ (c. 11.5 ka; Table 2; Fig. 5B; Supplement Fig. 3E), These tephra are locally reworked by slack water deposits, and finally buried by grey and orange loesses, latterly reworked by a thin loessic stacked moraine (Fig. 5B). Down to Hólmatungur, these deposits are remolded by a large series of palaeolacustrine beaches attesting to an ephemeral palaeolake (Van Vliet-Lanoë et al. 2005) between 380 and 200 masl down to the Vestudalur terrace (Figs. 4, 5A). Two kilometers upstream of Hnausar, a complex morainic arc, at 390 masl, has been pierced by a flood along the Sauðadalur (Fig. 4 -5D). 
Further upstream, an esker that issued from Lake Eilífisvötn (Fig. 4) joins the valley at Norðurfjöll,10 $\mathrm{km}$ further south, at ca. 400 masl, and has been partly eroded by flood waters below 380 masl.

On the right-bank, in front of Vesturdalur, the Hólssandur site (Kvensöðull) forms a wide terrace above the jökulsá canyon (Fig. 4). New observations have revealed highly visible asymmetrical-triangleshaped remains of a morainic arc (Fig. 6C) that have been strongly eroded by floods. These relicts correspond to the Hnausar terminal moraine (Figs. 1B, 4). A fresh and broad splay of fine basaltic sand (Fig. 6A, B) was deposited at $2 \mathrm{~km}$ to the north, as a field of large fluviatile dunes, up to 380 masl and about $220 \mathrm{~m}$ above the present-day river (at 160 masl). These dunes lap onto intact orange loesses that contain a rhyolitic tephra, the Askja E (10.4 cal ka) and are surrounded by a dismantled lava flow from the c.10.8 cal ka Askja dyke, the cones of which have been abraded by jökulhlaups to c. 280 masl. The dune splay was formed on two successives phases, one subhorizontally laminated, the second incising and reworking the first deposit with megaripples. The end of alluvial sedimentation is recorded in impounded levels at the southern ends of the deposits. These deposits argue for a very limited slope at the time of the floods, and a flood trajectory located to the east of the canyon.

\subsubsection{Hrossaborg tuff ring (close to the road N1)}

The Hrossaborg tuff ring (Fig. 2B) is located in a graben in the middle of a valley. It consists of a phreatomagmatic cone, truncated and abraded by jökulhlaups (Alho, 2003), resting on a terrace, at 380 masl. One kilometer upstream, and to the west of the Hrossaborg crater, we observed the well visible asymmetrical-triangle-shaped $10 \mathrm{~m}$ high remains (Fig. 7A) of a morainic arc that has been strongly eroded by jökulhlaups. It is probably one of the traces within the valley axe of a younger advance compared to Hnausar, between Dettifoss and the Heirðubreid (Fig.2B).

\subsubsection{Uppermost valley of the Jökulsá á Fjöllum (10 km north of the Vatnajökull)}

In the uppermost valley of the Jökulsá á Fjöllum, the Vaðalda Volcano is sparsely splayed on its west flank by fresh basaltic tephra, to a limited altitude, $200 \mathrm{~m}$ above the Dyngjuvatn Lake surface. Field and image observations have revealed that fresh tephra fills the lake that occupies the crater depression (Fig. 7D). An associated train of large, flat slackwater dunes, subhorizontally laminated and now consolidated (25 m wide, $50 \mathrm{~cm}$ high; Fig. 7D), covers the Dyngjuvatn palaeolake surface up 
to 688 masl. This deposit seems related to the rapid drainage of a larger lake, 'dammed' between the Askja caldera and Vaðalda Volcano. The lake was issued from the Dyngjujökull Glacier (Fig. 1). The dark, fine basaltic sand splay extends to the north, through Vikursandur, to the foot of the Heiðubreiðartögl tuya, ending $1 \mathrm{~km}$ north of the confluence of the Jökulsá and Kreppa Rivers. It reappears downstream, where it continues forming discrete terraces. These are higher in the topography than the jökulhlaup features formerly described which splayed closer to the present course of the Jökulsa River (Alho 2003, Alho et al. 2005; Carrivick et al.2013),.

The Kreppa River runs from the Brúarjökull outlet glacier (Fig. 2B), via the Kverká River, to the extension of a major and incised subglacial plain (Björnsson, 2009). Downstream, in front of the Heirðubreið Tuya, a dead valley diverges from the Kreppa River to the East, piercing a subglacial volcanic ridge, and producing a giant, fresh basaltic crevasse splay with megaripples ( $20 \mathrm{~m}$ wide). This abandoned channel is now drained by the Arnardalsá River, at $3 \mathrm{~km}$ to the North of a relatively fresh, thin terminal moraine (Fig. 7B), which was issued erratically, straight from the Brúarjökull Glacier and draining it. This moraine is only present on the eastern side of the Arnardalsalda hill, where it covers the trace of an ancient braided channel. It was pierced by a jökulhlaup and further incised by retrogressive scablands (Supplement Fig.1). .

\subsubsection{Synthesis for the Jökulsá á Fjöllum valley}

Advances and deglaciation

The Bölling deglaciation occurred quite far inland, south of the Peistareykir Volcano (Figs 1,3), prior to 10.8 cal ka (Askja S Tephra; Sæmundsson, 1992, 2002; Sigurgeirsson, 2016). This means that the YD glaciers occupied the valleys, as shown by the presence of the Vedde Ash in a juxtaglacial position at Hnausar (Fig. 5B), but the plateaus were only locally occupied by isolated ice-domes. The tephrostatigraphy justifies an early deglaciation for the surge moraine, morainic arc and formation of the Hnausar palaeolake, followed by the injection of the Hljóðaklettar rootless eruption (Figs 5, 6) estimated at c. $11-10.8 \mathrm{cal}$ ka (Sæmundsson et al. 2012; Sigurgeirsson, 2016) issued from the Askja fissure system. The position of the main Preboreal moraine (ca $11.2 \mathrm{cal}$ ka) was thus immediately south of Hólssandur and at Hnausar.

The morainic arc preserved upstream close to the Hrossaborg is necessarily younger than Hnausar, and it possibly corresponds to a glacial advance at ca 10.3 cal ka. This is henceforth called the 
Hrossaborg Advance. The upstream of Mororudalur, the single morainic arc issued straight from the Brúarjökull outlet glacier, despite the hilly morphology, remains untouched by large jökulhlaups (Fig.7B), excepted to the West. This advance is older than the Little Ice Age and potentially corresponds to the "9.3 cal ka" advance. The traces of this advance - probably a sudden surge - in the upper valley, are hereafter called the Kreppa Advance.

\section{Jökulhlaups}

Some early jökulhlaups occurred before the deposition of the Vedde Ash; some of them had already eroded the surface prior to the occurrence of the 11-10.8 cal ka cinder cones, but after the Preboreal Advance. The rupture of the Hnausar morainic arc developed more or less synchronously with the palaeolake formed during the 11.2 cal ka deglaciation, after the deposition of the Askja PB tephra (11.5 cal ka). The recent incision of the canyon was reaching the valley bottom probably prior to the infilling of the Younger Dryas glacial advance, but the re-incision by the Holocene floods had not yet been achieved at $11-10.8 \mathrm{cal} \mathrm{ka}$, during the setting of the Askja S lava lake (Sigurgeirsson, 2016). The Hólssandur fluviatile dunes are younger than the setting of the Askja $S$ fissure eruption. The geochemistry of the dunes (samples Hols 1, 2, Table 2) yielded a Bárðarbunga source. It is very similar to that of the upstream fluviatile dunes at the foot of the Vaðalda Volcano (Dingjuvatn Dunes $\beta$ ) from which the northern termination resembles the Hoblssandur fluviatile ones. Both dunes partly rework, and lap onto the orange loesses at Hólssandurthat included the Askja E Tephra (c.10.4 cal ka; Table 2, Hols 3). The only Bárðarbunga tephra that fit with this stratigraphy are those at 10.1 and 9.9 cal ka from the database (Table 1), the 9.9 cal ka event being the largest volcanic event (Guðmundsdóttir et al. 2016). The Hrossaborg terminal moraine remained strongly eroded by jökulhlaups that should fit the same event. The Kreppa terminal moraine (ca $9.3 \mathrm{cal} \mathrm{ka)}$ although eroded to the West was just pierced by a younger flood issued from the Kverka River related to a major volcanic eruption close to 9.2 or $9.1 \mathrm{cal}$ ka from the Grimsvötn volcano. It probably corresponds to the event formerly described (Alho et al. 2005; Carrivick et al. 2013).

\subsection{Skjálfandi-Fnjóskadalur}


The valley of the Skjálfandafljót is a little-studied area (Figs. 2 and 9), but it is the regular path of jökulhlaups (Björnsson, 2017). The upper valley is partly masked by the Middle Holocene lavas from the Trölladyngja Volcano (<4.2 cal ka; Sigurgeirsson et al. 2015; Fig. 2A).

\subsubsection{Lower Valleys of Skjálfandi and Fnjóskadalur}

This part is the most studied (Fig.8) on very few sections. We have thus described new ones and analysed the tephra. The estuary has been ice-free since the Preboreal (11.2 cal ka; Norðdhal and Pétursson 2005). The Bárðardalur Valley (Fig. 2A) was mostly incised in the bedrock, as close to Fosshóll scabland, with lateral moraines bordering the lower valleys. Eemian, hyaloclasite-derived, bioturbated marine deposits crop upstream out as pillars, along the valley bottom to 240 masl, from the entrance of the lateral Fnjóskadalur.

At the eastern entrance to Fnjóskadalur, thick, massive deposits of fresh basaltic gravels are buried under the recent loess along with the Askja S Tephra (11-10.8 cal ka; Fig. 10E). Inside the Fnjóskadalur, the 'pitted' moraine at the western end of the lake (at Stórutjarnaskóli) is considered to be from the Preboreal advance (Figs. 8, 9A; Ingólfosson et al. 1997). It is truncated by a terrace at 120 masl from the Fnjóskadalur palaeolake, but to the north, there is evidence of it being in a juxtaglacial position, with iceberg thermokarst filled with fresh basaltic sands (Bárðarbunga, $11.3 \mathrm{cal} \mathrm{ka,} \mathrm{Table} \mathrm{1;}$ Table 2: Ljos2). These deposits also reworked an Askja tephra much older than the Askja S (Askja PB, c. $11.5 \mathrm{cal} \mathrm{ka),} \mathrm{deforming} \mathrm{very} \mathrm{coarse,} \mathrm{rounded} \mathrm{gravel.} \mathrm{It} \mathrm{is} \mathrm{usually} \mathrm{covered} \mathrm{by} \mathrm{loesses,} \mathrm{including}$ the Askja $S$ tephra. The moraine morphology resembles the collapse features described by Fard (2002) on jökulhlaup eskers, and by Olszewski and Weckwerth (1999) on sandurs. The lower alluvial unit of the kame along the pitted moraine contains both reworked Vedde and Skógar Tephra (Table 2: Ljos 1). Downstream of Fnjóskadalur, below Hólls, the side of the valley is pasted by lacustrine and alluvial deposits resting on coarse till, including several layers of fresh basaltic sands reworking the Vedde ash (Fig. 9C). These deposits are covered conformably by deformed loesses that incorporated the in situ but deformed Askja PB Tephra at its base (c.11.5 cal ka; Fig.9E).

Two main morainic arcs are preserved in the parallel Aðaldalur Valley. The Fragarness arc is a disrupted terminal moraine (Fig. 8). The related Palmholt Quarries (Fig. 8; Supplement Fig 4), host broad, flat-bottomed kettle holes, which are invaded by deformed flood gravel layers and reworked basaltic tephra. The morainic material is sandwiched between two generations of jökulhlaups, the 
lower one reworking the Vedde tephra. The more recent generation accommodates decametric kettle holes. The late loessic sedimentation is similar to these of Fnjóskadalur including Askja Tephra. A later morainic arc, partly eroded, exists upstream, at the Laugar village.

\subsubsection{Upper Valley, the Bárðardalur and Vosnaskarð depression}

The morphology in the Bárðardalur Valley is only erosional and partly masked by Middle Holocene lavas from the Trölladyngja Volcano (< 4.2 cal ka; Sigurgeirsson et al. 2015; Fig.2B). Hníflar palagonite pinnacles are flood-sculpted in the central part of the Vosnaskarð depression (Fig.2B). A palaeolake occupied this depression, at a higher altitude (1100 masl) than the Vaðalda Volcano and palaeolake Hágongulón (see § 4.5).

Fresh glacial striae are oriented towards the Skjálfandafljót from the upper Sprengisandur (Fig. 2A). One terminal moraine is observed NW of Svartárvatn Lake, restricted to the right side of the canyon of the Bárðardalur Valley, a (Fig. 2A; Supplement Figs. 5A - 5B). The canyon was probably infilled by rather old tills and lacustrine deposits, as preserved on the left bank of the canyon at Halldórsstaðaskógur (Fig. 2A, Supplement Fig. 5C). Sandy basaltic deposits are splayed on the plateau, upstream and around the Svartárvatn Lake. The stratigraphy at Svartárkot clearly indicates a Bárðarbunga Tephra (probably 10.4 cal ka; Table 2), followed by the Reistvik 8 Tephra (10.2 cal ka; Guðmundsdóttir et al. 2016). SE of the Svartárvatn Lake, the Reitsvik 8 Tephra (Table 2, Svartár) is preserved in the upper part of the consolidated orange loess, but has been laterally eroded in a NE direction by jökulhlaups.

Another structure is visible to the NE of Svartárkot, on the plateau, near the Sellandafjall Tuya. These structure shaped the surface of the Kárkárbotnar Formation which is consolidated and faulted palaeofan considered as Late Glacial and initially scoured after the YD Advance (Sigurgeisson et al. 2015). An alluvial splay of granules and sands shaped the surface of Kárkárbotnar Formation into fluvial megadunes (two generations) and residual hillocks (Figs. 2A and Supplement 12) based on aerial views. This surficial morphology is associated with an esker (Fig Supplement.12 E) that propagated subglacially to Myvatn Lake from the north of Krákárbotnar, parallel to the present Kráka River. The final evidence of flooding is here the splayed sands stopping at the western foot of the Sellandafjell and associated with the sculpting of elongated islands in the loess cover 
435 (Supplement.12). From these data, and the location of the terminal moraine in the Bárðardalur Valley,

436

437

438

439

440

441

442

443

444

445

446

447

448

449

450

451

452

453

454

455

456

457

458

459

460

461

462

463

464

the Kárkábotnar initial superficial scouring could be generated by the same events as these recorded at the Svartárvatn Lake, a part of the flood(s) deriving towards the Myvatn Lake to the east (Fig. 2A).

4.3.3 Synthesis for Skjálfandi-Fnjóskadalur- Myvatn-Vosnarskard system

\section{Glacial advances and retreats}

In the Bárðardalur and Adaðalur Valleys, (Fig. 8), the basal fluvial sediments have reworked the Vedde Ash as also observed at Laufas and Kaupangur in Eyafjöððr (Sigurðsson and Sparks 1978; Van Vliet-Lanoë et al. 2005). Ljosavatn and Palmholt quarries reveal dismantled glacier ice tongues that represent a rapid advance or a surge. The Skjálfandi terminal moraine was located in the vicinity of Skollahnjúkur as suggested by a perched pitted morphology at 200 masl (Fig.8). This surge can be attributed to the "11.2 - 11.4 cal ka" Preboreal event (tephrostratigraphy; Ingolfsson et al. 1997), formed before the deposition of the Askja PB and S Tephra. By deduction, the "10.3 cal ka" terminal moraine could be restricted to these at the Laugar village. Upstream, the lateral moraine immediately NW of Svartárvatn Lake most probably yields an age of ca $9.3 \mathrm{cal} \mathrm{ka,} \mathrm{based} \mathrm{on} \mathrm{tephra} \mathrm{(younger} \mathrm{than}$ the Reistvik 8 Tephra at 10.2 cal ka). This is the proposed Svartárvatn Advance.

\section{Jökulhlaups}

The oldest basal generation of flood immediately postdates the Vedde Ash and represents an early stage in the Preboreal deglaciation. The main (second) generation of floods predates the Askja $S$ Tephra (10.8 cal ka), thus yielding $11.2-11.1 \mathrm{cal} \mathrm{ka}$ in age. The third generation took place before the first Bárðarbunga eruption (10.4 cal ka; Guðmundsdóttir et al. 2016) and the overlying Askja E Tephra (10.4 cal ka). The latter generation (last terrace) is logically related to eruptions of the Bárðarbunga at c. 10.1 or 9.9 cal ka (Table 1; Guðmundsdóttir et al. 2016). Flood deposits from the Skalfandafljót River were also washed into Fnjóskadalur and Eyjafjörour via the Dalsmynni Canyon (Hólls and Finnastadir Farm; Figs. 4, 8D). This path for floods explains the water-lain facies of the "10.3 cal ka Saksunarvatn Tephra" observed at Reitsvik (Guðrmundsdóttir et al. 2016).

The surface granular components of the Krákárbotnar palaeofan (Sigurgeirsson et al. 2015) had probably the same source and age as the deposits at Svartárkot, based on the orientation to the NE of 
the megadunes. All these floods seem to issue from the Dingjujökull outlet glacier (Table 1, Fig.2B) and to correspond to the Bárðarbunga 10.4, 10.1 and mostly 9.9 cal ka tephra. These floods probably had a long duration (weeks or more), as they were mainly fed by deglaciation, justifying their lateral displacement to the east by the Coriolis force feeding the Myvatn basin. Re-incision in Preboreal glacigenic sediments of the Bárðardalur valley after the Preboral glacial advances occurred much later, prior to $7 \mathrm{cal}$ ka, but probably from ca $9.3 \mathrm{cal}$ ka.

\subsection{Jökulsá á Brú and the East}

\subsection{1: Halslón palaeolake}

To the NE of the Vatnajökull, sparse evidence of jökulhlaups has been recorded in the Halslón Dam sedimentary fill that was issued from the western Brúarjökull outlet glacier, via Kringislá (Knudsen and Marren, 2002). The stratigraphy of the Holocene events has evolved from the ones previously published (Knudsen and Marren, 2002; Van Vliet-Lanoë et al. 2010). The LIA moraine is located north of the Kringslaranni, on both sides of the dam lake, followed by successive termini. A terminal moraine older than the LIA is visible North of Hals, on the right bank of the lake (Fig.1b), fitting the 9.3 cal ka advance.

Jökulhlaups reworked first the Younger Dryas Grímsvötn Tephra, filling troughs with massive deposits (Van Vliet-Lanoë et al. 2010), that were further deformed by a first glacial advance. An Askja E Tephra (10, 2 cal ka comparable to Vestur R3 in Table 2; Fig. 7C) has been deformed by a second glacial advance. The Saksunarvatn Tephra was water-lain in the highest terrace and deformed as a thermokarst depression in a juxtaglacial position (Fig. 7D). Laterally, it is undeformed, and post-dated by a faulted geyserite at $10.09 \pm 0.28 \mathrm{ka}$ BP (U-Th uncorrected dating; Van Vliet-Lanoë et al. 2007; Fig. 7E).

The Jökulsá á Brú River is deeply incised down from the Brú village, similar to the canyon of the Jökulsá á Fjöllum. Two remains of terminal moraines were preserved. Downstream, a 'pitted' moraine is visible on the left bank, at $1.5 \mathrm{~km}$ south of Selland, below a large mass flow on the right bank. This is probably an end moraine from the Botarheiði that evolved into a rock glacier. Further down, another 1.5 km long "pitted" end moraine crops out near Krókavatn (Fig. 1b).

\subsubsection{The Eyabakkajökull}


495

This glacial outlet shows traces of stacked, permafrosted ice-thrust ridges, comparable to several Svalbard glaciers (Boulton et al. 1999; Sund et al. 2009; Waller et al. 2012). They formed in relation with the 1890 surge and commonly attributed to hydraulic surging (Sharp, 1985; Kaldal and Vikingson, 2000; Björnsson et al. 2003; Schomacker et al. 2014, Fig. 11). The southern eastern part is a rather thin diamicton and associated with a negative inprint of ice crevices and a narrow sharp plastic edge and stacked folds of a surge fitting the 1890 one (Schomacker et al, 2014). The northernmost / outer part of this moraine seems to be partly older, seeing the thermal cracking and vegetation cover which are similar to the situation on the recent volcanic ridge at Veiðivötn (1477 AD eruption). For the nearby Brúarjökull Glacier, the presence of a glacier-deformed Öræfajökull Volcano pumice (1362 AD eruption; Benediktsson, 2012) suggests a setting during the coldest part of the Little Ice Age, from 1600 AD to 1800 AD (Guðmundsson et al. 1997). The Mülajökull Glacier had its maximal advance between AD 1717 and 1760 (Benediktsson et al. 2015). The persistence of relict morainic arcs within a palsa bog immediately downstream of the Eyabakkajökull terminal should indicate a long, unglaciated interval, at least from the 9.3 cal ka advance. Furthermore, a field of open-system hydrolacolite occupies the western side of the valley, attesting of the limited glacial extent to this side. Several jokulhaups have pierced the arc, mostly to the West, in association with an esker, but it does not seem possible to build a chronology.

Observations were performed downstream at the Lögurinn Lake (Fig. 1): the deglacial sedimentation covered an interval from $10.2 \mathrm{cal} \mathrm{ka} \mathrm{(Strinberger} \mathrm{et} \mathrm{al.} \mathrm{2012;} \mathrm{Guðmundsdóttir} \mathrm{et} \mathrm{al.} \mathrm{2016;} \mathrm{Norðdahl} \mathrm{et}$ al. 2019), fitting an age of 11.2 cal ka for the terminal moraine north of Eglisstaðir (Fig. 1).

\subsubsection{Synthesis.}

\section{Glaciers}

At the Halslon Lake, the older Grímsvötn Tephra has been reworked in flood troughs in association with the Bölling deglaciation (Fig. 10). The Boreal advance is slightly younger than $10.4 \mathrm{cal}$ ka (Askja E Tephra) at the foot of the Kárahnjúkar Tuya (Fig. 7C). This corresponds to a "10.3 cal ka" advance, synchronous with the Hrossaborg and Laugar events. Laterally, the "9.3 cal ka" terminal moraine from the Brúarjökull Glacier reached the deformed Saksunarvatn Tephra in the middle of the length of the Halslón Lake, equating with the Kreppa-Svartarvatn Advance to the west. 
524 To the East, the Eggilstadir moraine yields c. 11.2 cal ka. The moraines relics in the palsa bog thus

525 yields c. 9.3 cal ka; the outer Eyabakkajökull stacked vegetated moraine with ice wedging and

526

527

528

529

530

531

532

533

534

535

536

537

538

539

540

541

542

543

544

545

546

547

548

549

550

551

552

Jökulhlaups

Megafloods first seem to occur prior to the YD. The Saksunarvatn Tephra splayed in a flood, being preserved intact in juxtaglacial position from a pre-existing surge lateral moraine, yielding probably c. 10.3 cal ka.

\subsection{The South-West: The Pjorsá-Kadakvís/-Tungnaá outlet}

The South-western main outlet from the Vatnajökull is drained by at least 3 valleys (Fig.1a). The Pjorsá-Kadakvísl-Tungnaá Valleys are clearly shaped by jökulhlaups over the last two interglacials (Van Vliet-Lanoë et al. 2018). This is proven by the occurrence of floods erosional forms (Supplement Fig.6). The Late Glacial sedimentary prism is rather thin, mostly located in the jökulhlaup incisions, sometimes infilled with sediments associated with the tidal deposits of the Preboreal marine transgression. Regional field descriptions are rare, and most of the data are being extracted from lake cores (Geirsdóttir et al. 2009). To the north of this system, data are non-existent or unpublished.

\subsubsection{Akbraut and Varghóll Quarries}

The section at Akbraut (Figs 1, 10) is located on a terrace perched at 90 masl on the east bank of the Pjórsá River. It is situated south of the Búði moraine complex, dated at ca. 11.2 cal ka (Geirsdóttir et al. 2009), and north of the Pula-Mykjunes terminal moraines (YDII, in situ Vedde Ash; Van Vliet-Lanoë et al. 2018). It has an infill of coarsely-stratified, unsorted and unconsolidated cobble material, set by jökulhlaups, which are incised into the Eemian and Weichselian deposits. These gravels are covered by stratified lacustrine silts, deformed by moderate seismic activity, as is also the case in the section at Hrepprhólar (Fig. 1), where they are related to Termination la. A second unsorted diamicton was deposited, which includes, at its base, fresh, dark basaltic sands that are coarsely stratified, and sheared by glaciotectonism (Vedde $\beta, 11.8$ cal ka, Van Vliet-Lanoë et al. 2019). This is covered by 1 
$\mathrm{m}$ of stratified marine silts (from Termination lb), including Vedde pumice-rich beds, with small load casts. This marine unit is further truncated by more recent jökulhlaup gravely deposits.

The Varghóll-Akbraut moraines correspond, in aerial view, to thin terminal moraines that are later than the YD, but older than the major Búor terminal moraine. These moraines present surge-type characteristics, with a stacked folded pattern. The suggested age, from the presence at the base of reworked Vedde Ash, is ca. 11.4 - 11.3 cal ka, followed by the 11.2 cal ka Búðí Advance.

To the West, "pitted" jökulhlaup abraded rocks (Supplement Fig. 7) crop at 230 masl on the Skarðsfjall (Fig.1A), disconnected from the natural drainage system. It suggests a discharge of water emerging from the surface of a thin decaying glacier lobe during the late YD or the Early Preboreal, probably from a crevice net.

\subsubsection{Upstream watershed of Pjórsá River}

Another terminal moraine was mapped by Kaladal and Vikingsson (1990) to the north, east of the Sultartangalón Lake. It is associated with an eroded esker deposit (Fig.12A). Herein, this terminus will be referenced as the Búðarhals Advance. At the hydroelectric station of the Pjórsá Lake, the base of the Late Glacial to the Holocene canyon infill is extremely rich in basaltic tephra, resting on an Eemian fluvial formation, as in the Upper Ytrí-Rangá Valley (Van Vliet-Lanoë et al. 2018).

Upstream, the Pjórsa River is connected to the artificial Hágögulón Lake (Fig. 1A). This lake' site was occupied several times by palaeolakes. At the eastern foot of the Nyðri Háganga Tuya, ca. $100 \mathrm{~m}$ above the original valley floor, the upper raised beach (at 887 masl) is covered by scattered fresh basalt fragments that were issued from the Bárðarbunga Volcano. This upper raised beach is at the same altitude as the tephra filled Vaðalda crater, east of the Askja Volcano (Figs 1, 2B). Another palaeolake outlet is perched at 860 masl, and is connected to a lake level located at $80 \mathrm{~m}$ above the valley floor, associated with a retrogressive dry valley, incised in an Eemian glaciofluvial deposit (Supplement Fig. 8E). Many jökulhlaup-polished blocks (Supplement Fig. 8A-D) are visible at 835 masl, $65 \mathrm{~m}$ above the valley floor, at a palaeo-outlet of the palaeolake. It seems that this palaeolake infilled several times, with up to $100 \mathrm{~m}$ of water for the oldest highstand, with evidence of flood bursting (incision). Damming was generated by westward ice surging from the Tungnaárjökull and Sylgjujökull outlet glaciers (Fig. 1, extent in yellow). This is evidenced by the morainic system that 
604

ends close to the Kisa River to the west (Fig. 7C; Kaldal and Vikingsson 1990), issuing from the north of the Sauðafell hill (North of Veidivötn). This is associated with evidence of lakes with terraces, and a field of open system pingos in silty sands, close to 850 masl, at SW of the lake. It is overlapped finally to the south by the Pjórsa Lava $(8.6 \mathrm{cal} \mathrm{ka})$. This terminus will be herein referenced as the Kisa Advance, surging from the Tungnaárjökull and Sylgjujökull outlet glaciers.

\subsubsection{Synthesis for the Pjorsá-Kadakvísl-Tungnaá outlet}

Following the Glacial Termination Ib, several glacial advances occurred in the south. The twinned advances of the YD I - Pula moraine (c. $12.8 \mathrm{ka} \mathrm{cal}$ ) - and YD II- Mykjunes moraine (c. 11.7 - 11.5 cal ka) - formed a major glacial terminus (Van Vliet-Lanoë et al. 2018).

Observations at Varghóll suggest a retreat from Mykjunes to the Búði arc, with pulsed surges associated with jökulhlaups and iceberg discharges (Figs 10,11) that correlate with a c. $11.4-11.3$ cal ka surge, the Varghóll - Akbraut Advance just after the YD deglaciation. The Búði Terminus fits the "11.2 cal ka" Preboreal advance (e.g. Geirsdóttir et al. 2009). The next glacial advance should correspond, in the south, to the Búðarhals Advance on the eastern side of the Kaldakvísl River. A later trace of glacial surge emerges from the East, between the Sandfell in the south and the Hágöngulón lake sector in the north, to the Kisa River, but this seems to have been untouched by jökulhlaups. Its source was hindered by the Pjórsá Lava, at 8.7 cal ka (Halldórsson et al. 2008), and seems to have issued from the Syglujökull and Tungnarjökull outlet glaciers, which normally surge westward (Björnsson et al. 2003). This places at ca. $9.3 \mathrm{cal}$ ka cal the Kisa Advance which is an erratic advance. This indicates an age of ca $10.3 \mathrm{cal} \mathrm{ka} \mathrm{for} \mathrm{the} \mathrm{Búðarháls} \mathrm{Advance.}$

\section{Discussion}

To understand the various potential controls on jökulhlaup genesis, we first discuss the climate evolution and deglaciation history for each outlet of the Vatnajökull. Second, we analyse the connection between glacio-isostasy and the potential storage of aquifers, or of subglacial lakes, at the level of the Vatnajökull. On this base, it will be possible to discuss the dynamics that drove the Early Holocene jökulhlaups.

\subsection{Timing of the Glacial Advances (Fig. 1 b)}


613 After the deglaciation of the YD and the deposition of the Vedde ash (ca $11.8 \mathrm{cal} \mathrm{ka}$ ), the Early 614 Holocene glacial advances of the Vatnajökull spreaded at ca 11.5-11.4, 11.3-11.2, 10.3 and 9.3 cal ka, 615 in concert with climate evolution in the other regions surrounding the North Atlantic (see § 3.1.).

616 The Varghóll - Akbraut in the South, Hnaussar, Ljósavatn and the Fragarness - Palmholt terminal 617 moraines in the North (ca $11.4-11.3 \mathrm{cal} \mathrm{ka)}$ correspond to the first Early Preboral advance. The Búoi 618 (c. 11,2 cal ka) is a second Early Preboreal Advance. The later Búdarhals Advance in the South is 619 estimated to be synchronic with the Erdalen Events and the Saksunarvatn complex tephra, at c.10.3$62010.2 \mathrm{cal}$ ka as well as the Hrossaborg, Laugar and Eglisstaðir termini in the North. For the independent 621 Langjökull on the West Volcanic Zone, the Saksunarvatn Tephra has been found below a lava flow 622 (Jóhannsdóttir 2007; Eason et al. 2015), also suggesting an early deglaciation, and isolation of the 623 southern and eastern margins of the glacier.

624 The Kreppa, Kisa, Svartárvatn and outer Eyabakkajökull Advances seem to be equivalent to the "9.3 625 cal ka" Cooling Event. They are characterized as erratic in their flow direction, compared to the Late 626 Glacial and Preboreal Advances. This late advance is also recognised around the Drangajökull Glacier 627 (NW peninsula; Harning et al. 2016).

628 The "8.2 cal ka" event has not been officially recorded in lacustrine records in the NE of the island 629 (Striberger et al. 2012); however, it is clearly recorded in cores at Hvitarvatn (Langjökull; Larsen et al. 630 2012; Fig. 1) and is also extractable from the ${ }^{3} \mathrm{He}$ measurements of volcano summit lava's tracing the 631 local deglaciation (Liccardi et al. 2007). This means that the glacial limits for this pulse were mostly inside the present extent of the glacier.

633

\subsection{Timing of the Jökulhlaups (Fig.2 B)}

635 In the Jökulsá á Fjöllum, major jökulhlaups thus occurred from our data in relation to the Younger Dryas deglaciation (Hnausar kame terrace), probably between 11.8 and $11.4 \mathrm{cal}$ ka, centred on 10.1 -

$6379.9 \mathrm{cal} \mathrm{ka}$ (Hölssandur) and ca $9.1 \mathrm{cal}$ ka south of the Hrossaborg. The major Icelandic jökulhlaups in 638 the literature relate to the onset of canyon clearance of the sedimentary infilling. After $9.3 \mathrm{cal}$ ka, some 639 events were still large, but were better channeled.

640 It thus seems that most of the early jökulhlaup events in the Pjórsá, Skalfandi, Jökulsá á Fjöllum and

641 Jökulsá a Brú valleys occurred from the Late Younger Dryas deglaciation, some having bursted just 642 prior to the Early Preboreal Advance (at $11.2 \mathrm{cal} \mathrm{ka).} \mathrm{The} \mathrm{jökulhlaup} \mathrm{mentioned} \mathrm{at} \mathrm{Kjölur} \mathrm{(Kajafell}$ 
643 Volcano, Langjökull) by Tómasson (1973) also seems to correspond to a first-generation surge (at 64412.0 to $11.2 \mathrm{cal} \mathrm{ka),} \mathrm{as} \mathrm{it} \mathrm{is} \mathrm{associated} \mathrm{with} \mathrm{iceberg} \mathrm{kettle} \mathrm{holes} \mathrm{and} \mathrm{two} \mathrm{eskers,} \mathrm{all} \mathrm{overflowed} \mathrm{by} \mathrm{the}$ 645 Preboreal lava (Eason et al. 2015).

646

647 In the South, after the Preboreal, the majority of flood events occurred after the Búðarháls Advance 648 ("10.3 cal ka"), but prior to the Kisa Advance (" 9.3 cal ka"). These field data fit the results from the 649 Hestvatn Lake record (Fig.1; Geirsdóttir et al. 2000) that assigned two major periods to the flood 650 activity around $12.0-11.2 \mathrm{cal} \mathrm{ka}$, and again around $10-9.9 \mathrm{cal} \mathrm{ka}$ as it is also the case for the 651 Jökulsá á Fjollum watershed.

652

\section{$653 \quad 5.3$ Permafrost and surging}

654 Outlet glaciers of ice caps that periodically surge after long quiescent phases, undergo large and 655 sudden pulses accompanied by terminus advance (Harrisson et al. 2015; Benn et al. 2019). 656 Polythermal glaciers, often associated with permafrost are prone to slow surging (Benn and Evans, 657 2011). The temperate glaciers in Iceland exhibit surges with a sudden onset, extremely high (tens of 658 meters/day) maximum flow rate and an abrupt termination, associated with a discharge of the intra659 glacier stored water (Björnsson et al. 2003). It can be triggered by an enhanced climate-driven melting 660 (Stiberger et al. 2011) or a volcanic meltwater supply. Ice breakage at the glacier surface or perched 661 outlets, with the local surface dismantling and iceberg splay, can be induced by constrained 662 overpressure (Roberts et al. 2000). The downward locking of hydraulic pressure can result from the 663 impeded drainage by permafrost development that seals the snout and margins of the glacier, frozen 664 to the bed during cooling events, as in the polythermal glaciers in Svalbard (Fig. 12D; Lonne et al. 665 2016).

666 The impact of the permafost seems evident for the Eyarbakkajökull outlet and the Kreppa, Kverká and 667 Jökulvisl River outlets of the Brúarjökull Glacier (evidenced by the recently pitted terraces). This 668 system with surface dismantling is also valid for the outlets of the Breiðamerkurjökull River, in 669 association with concertina eskers (Knudsen, 1995), for the Gígjulvísl and Skeiðará Rivers 670 (Skeiðarárjökull Glacier) and the uppermost Tugnaá River.

671 As the Preboreal climate was rather cold especially during the two first Bond events, particularly in the 672 North-East (about $-10^{\circ} \mathrm{C}$ lower than today; Rasmussen et al. 2011), we might expect the impact of 
673

permafrost damming to be one of the main triggers of jökulhlaups.The preserved pre-jökulhlaup morphology suggests such permafrost prior to the principal Early Holocene flood, also deformed by tectonic faulting to the east (Fig. 14C). The degradation of ice bodies in the terminal moraine during a warming event could have reduced the internal stability of the dam and, therefore, easing flood emergence (GAPHAZ 2017). Sealing of the glacier tongue by permafrost could have favoured the retention of meltwater in the subglacial lakes or intraglacial aquifers, especially if the surface and bottom slopes were very low (see $\S 5.2$ ), increasing the probability for glacial surging for both polythermal and temperate glaciers (Benn et al, 2019). Proglacial icing accumulations from eskers could also have induced damming. This was likely the case for the glacial tongues reaching the lower Skálfandi River (at Ljósavatn and Palmholt) and the lower Pjórsá River (at Varghóll), around 11.2 cal ka. After 10.4 cal ka, jökulhlaups were largely splayed on the deglaciated plateaus, The occurence of permafrost in the watershed probably limited the vertical incision of any flood, promoting a lateral extension of such floods in the valleys, as it took place with the first mega-jökulhlaup, responsible for the Hỏlssandur hydraulic dunes (Jökulsá á Fjöllum), or the Svartárvatn-Krákárbotnar jökulhlaup (at Skjálfandafljot).

\subsection{Impact of the glacio-isostatic rebound}

As the c. $10.8 \mathrm{cal}$ ka Askja S Tephra and the c. $10.3 \mathrm{cal}$ ka Saksunar events happened relatively soon after Termination $\mathrm{Ib}$, an early glacial rebound from the coast to the inland, should be expected attenuating the slope of the lower to middle Jökulsá Valley. The distance from Röndin to the Hrossaborg moraine is about $50 \mathrm{~km}$, and is being uplifted at rates similar to those in the south of the isle, c. 40 to $60 \mathrm{~mm} \mathrm{yr}^{-1}$ (Le Breton et al. 2010). Present-day isostatic uplift around the Vatnajökull is 9 to $25 \mathrm{~mm} \mathrm{yr}^{-1}$ (Pagli et al. 2007). The persistence upstream of an extended Vatnajökull suggests that this sector is still downwarped in relation to the remaining ice thickness, and the presence of the hotspot (due to lower viscosity). An initial subsidence of $500 \mathrm{~m}$ is expected at the LGM for a $1500 \mathrm{~m}$ thick ice sheet. Supposing that half of the ice-sheet thickness (ca. $750 \mathrm{~m}$ ) has already melted at 10.3 cal ka, we could theoretically expect a residual subsidence of $250 \mathrm{~m}$ in the central part of the system, and half of that $(125 \mathrm{~m})$ in the outlet zone of the Hrossaborg and Buðardalur surging tongues. This simple but certainly overestimated approach allows imaging of the potential extent of subglacial lakes or aquifers (Fig. 13) which are retained below the residual thinned flat ice-sheet (slope ca $4 \%$, 
subglacial volcano excepted), and adapted from the subglacial topography described by Björnsson (2017). Due to the speed of the rebound (ca $25-40 \mathrm{~mm}$ yr-1 from the present-day values) imposed by the fracturated substratum (Höskuldsson et al. 2006; Le Breton et al. 2010), this isostatic rebound had very little chance of strongly modifying the geometry of the meltwater catchment areas for the brief interval ( $\left.10^{2} \mathrm{yrs}\right)$ considered, but the isostatic subsidence was certainly resorbed after $1 \mathrm{ka}$, as in the "9.3 cal ka" deglaciation.

\subsection{Volcanic activity, jökulhlaups and unloading}

Glacial unloading could directly influence the activity of volcanoes by adiabatic crustal melting (Eksinchol et al. 2019). The Grimsvötn and Bárðarbunga Volcanoes were partly merging from the ice sheet since $18 \mathrm{cal}$ ka and mostly from $11.8 \mathrm{cal}$ ka (Van Vliet-Lanoë et al, 2019). With the ongoing rapid warming from $11.8 \mathrm{cal}$ ka (Fig.3), the glacial unloading of the western Vatnajökull allowed the supply in magma in the deep subcrustal reservoirs of the NVZ and EVZ (Hartley and Thordarson, 2013). This supply fed first the Grimsvötn and Bárðarbunga reservoirs (see tephra record, Table 1). The Askja Volcano is presumed deglaciated around 10.3 cal ka only (Hjartarson, 2003; Hartley and Thordarson, 2013), but it was fully emerged from $11.4 \mathrm{cal}$ ka. The PB Tephra was followed several smaller eruptions (Fig.10; See Supplement Fig.4), before the major Askja S. The Saksunarvatn Tephra $(10.24-10.12 \mathrm{cal} \mathrm{ka})$ has a more complex story.

The potential triggering effect on eruptions of small unloading events, such as water discharge from a lake and ice thickness variations, has been demonstrated when the underlying magma chamber is close to failure conditions comparable to the static stress change induced by earthquakes $(1-10 \mathrm{kPa}$; Albino et al. 2010). Today, ice loss reaches $6 \mathrm{~m} \mathrm{yr}^{-1}$ for the Vatnajökull (http://Vedur.is). The climatic unloading reaches $60 \mathrm{kPa}$ after 100 years of warming, with a potential effect on the upper reservoir of the Grímsvötn Volcano.

Thermal analysis at the Kverkfjöll Volcano has indicated that a jökulhlaup must have taken place a few days after the initial subglacial lava emplacement (Höskuldsson et al. 2006). Maximal ice melting rates of the order of $10^{3} \mathrm{~m} \mathrm{~s}^{-1}$ have been indicated. The magma must have reached water content close to saturation at emission allowing the onset of a phreatomagmatic eruption after lake drainage 
733

(Höskuldsson et al. 2006). It also lowered the melting temperature of magma and the spreading of extensive lava flows (Wylie et al. 2000), as observed immediately after deglaciation. This interpretation suggests that jökulhlaups reactivate eruptions by lowering the pressure on the magma chamber (Höskuldsson et al. 2006; Albino et al. 2010).

The expected succession for deglacial events are thus: 1) subglacial eruption; 2) lake formations; 3) jökulhlaup and iceberg discharge, or possible glacial surge; and 4) phreatomagmatic ash emission. This succession could occur rather rapidly, within a few weeks, or be recurrent as a part of the 10-year cycle for Grímsvötn volcanic activity and is most likely for summer events, especially if the perturbation is within a range of $7 \mathrm{kms}$ from the centre of the reservoir (Albino et al. 2010). Climatic glacial unloading, at present values, seems to be enough to induce a first eruption of the upper reservoir.

\subsection{Climatic melt control and jökulhlaups}

Jökulhlaups have been recorded from the Alleröd cooling (ACE Fig.3), even during brief events in the Younger Dryas, especially in the NE of the isle, commonly starved in precipitation. The onset of warming would have raised the water level in subglacial lakes, favouring surges (e.g. Russell et al. 2001). From 10.25 cal ka BP, warming was significant, producing temperatures similar to those of today (see § 3.1). Restoration of the Irminger Current favoured a rise in precipitation. Rapid ice melting could have been driven by intense late-summer rainfall, causing the thinning of large ice-sheet at low altitudes (Doyle et al. 2015). Surface melt-lakes represent today ca. $1 \mathrm{~km}^{3}$ of the decaying part of the Greenland ice-sheet (Fitzpatrick et al. 2014). The depression below the Brúarjökull outlet glacier (Brúarjökull Lake; Fig. 16) is the largest, but with an "impermeable" bedrock. This glacier surged first. Traces indicate that surging certainly issued from the west of the Brúarjökull in both of the latter events, the "10.3" and "9.3 cal ka" ones. The surge responsible for the Hrossaborg Advance ("10.3 cal ka") clearly dammed from the north the depression south of the Vaðalda and Askja Volcanoes. This explains the Dingjuvatn Dunes and the splay of dark tephra on the western flank and in the crater of Vaðalda, to $200 \mathrm{~m}$ above the valley floor, emitted by ca 10.1 and/or $9.9 \mathrm{cal}$ ka eruption of the Bárðarbunga. The Kreppa Advance ("9.3 cal ka") mostly dammed the Jökulsá á Fjöllum, and was probably responsible for the high flood described by Alho et al. (2007). Both flood series (c. 10.1-9.9 cal ka and $<9.3 \mathrm{cal} \mathrm{ka)}$ were initially linked to ice-damming. Today, most outlet glaciers in Iceland are 
thin, plastic and temperate-based surging glaciers (Bjornsson, 2017). These could be more susceptible to recurrent overpressure compared to the colder surging glaciers (Ben and Evans, 2010) that existed in Northern Iceland during the Preboreal and that probably needed higher overpressures to breach a permafrosted dam.

As the ' 10.3 cal ka' events seem to have been rather synchronous with the Askja, Grímsvötn and Bárðarbunga eruptions, a supplementary melt is expected from the splay of ash on the surface of the glaciers. A lowering of surface albedo could have further increased the melting efficiency by $60 \%$ (Vogfjörd et al. 2005; Möller et al. 2013). The low albedo measured in 2005 is related to the 2004 Grímsvötn eruption (Möller et al. 2013) that was immediately followed by a jökulhlaup (Vogfjörd et al. 2005). This is also valid for the Gjálp eruption in 1996 (Guơmundsson et al. 1997; Björnsson, 1998; Russell and Knudsen, 1999). Insolation has been rising since $10.29 \mathrm{cal}$ ka, to a high between 10.20 cal ka and $10.05 \mathrm{cal} \mathrm{ka,} \mathrm{with} \mathrm{a} \mathrm{maximum} \mathrm{value} \mathrm{of} \% \delta^{14} \mathrm{C}$ at $10.13 \mathrm{cal} \mathrm{ka}$ (Stuiver et al. 1998; Fig.2), enhancing ice sheet collapse. Intervals of positive mass balance for the glaciers have conversely lowered the volume and frequency of recent jökulhlaups (Guômundsson et al. 1995). It thus seems that the first large eruption took place subsynchronously with the breakage of the ice-dams north of the Vaðalda, at ca. $10.2 \mathrm{cal} \mathrm{ka,} \mathrm{in} \mathrm{agreement} \mathrm{with} \mathrm{ice-core} \mathrm{dating.} \mathrm{The} \mathrm{Bárðarbunga} \mathrm{Tephra,} \mathrm{observed} \mathrm{at}$ the base of the Svartárkot Tephra sequence, probably fit the ca 10.45 cal ka event (Guðrmundóttir et al. 2016), or possibly another event closer to $10.25 \mathrm{cal}$ ka, masked by the volume of Saksunarvatn Ash. In the following years, insolation rose to a maximum, and melting was enhanced by the first large ash splay. Local eruptions blasted from Grímsvötn with the discharge of the caldera lake, with a frequency close to the usual 60 -year cycle during the century to $10.12 \mathrm{cal}$ ka, thus filling the subglacial lakes.

\subsection{The complex history of the Saksunarvatn event and associated jökulhlaups}

Phase 1 - Glacial rupture and lake drainage ca. 10.3 cal ka: the aerial Vaðalda Lake (Fig.10) was icedammed by the surge of the Bruarjökull (Kreppa advance, to $200 \mathrm{~m}$ water depth) and fed by climatic melt. But it is too far from both the Grímsvötn and Bárðarbunga Craters to have influenced the reservoirs mechanically. Subglacial lakes as the Brúarjökull Lake or aquifers, also climate-fed, have expanded probably to the edges of the Grímsvötn caldera. An initial breaching or lifting of the 
793

permafrosted glacier margin down from the Vaðalda Lake, followed by the drainage of subglacial lakes / aquifers may have been associated with unloading and the first volcanic event, close to the cold Erdalen Events - "10.3 cal ka" - in relation to the shallowest magmatic chamber. The other possibility also exists: with this subglacial eruption, the input of warm water would have increased suddenly as today (Snorrason et al. 1997; Björnsson 1998; Russel et al. 2002), the subglacial water pressure, allowing hydraulic fracturing, buoyancy and subsequent ice-dam rupture.

Phase 2 - Main volcanic activity ca. 10.25 cal ka: Based on the sizes of the Brúarjökull and Vaðalda Lakes, it is plausible that the deepest reservoir at Grímsvötn could have been triggered by this forced drainage, promoting the main phreatomagmatic ash eruption, the main Saksunarvatn event and the Skeidarar jökulhlaup (Lacasse et al. 1998). Massive basaltic ash deposition occurred during the diminution of the flood, and on all the slackwater deposits along the upper Jökulsá á Fjöllum Valley. The drainage of the caldera to the south (via the Tungnaá River) probably occurred with a second eruption, as similar to the occurrence of the delayed triggering of the Bárðarbunga eruption (at 10.15 cal ka). Several high floods thus emerged during the ca $10.24-10.15$ cal ka period in the whole Jökulsá Rivers of the Vatnajökull. Furthermore, these events seem to have had a limited erosional capability, probably due to low-angled slopes and the persistence of permafrost, particularly during the Preboreal.

Phase 3 - The Bárðarbunga and Grímsvötn late response, 10.15-9.9 cal ka: The 10.15 cal ka eruption of the Bárðarbunga Volcano occurred in a similar way to that at Grímsvötn (10.25 cal ka) - by the disturbance of deep magmatic reservoirs. This interpretation probably also fits the ongoing deglaciation between the volcano and the western Tungafells outlet glacier, allowing massive storage in the natural-aerial Hágöngulón and Vonarskarð Lakes (Fig.13), resulting in flood escapes through the Vonarskarð Lake to Skjálfandi. Icebergs were apparently included in the jökulhlaup deposits, along with ash-rich deposits from the slack waters. The major jökulhlaup at 9.9 cal ka had already occurred by the onset of the next cooling, due to insolation, and is recorded in the Pjórsá Valley on the Akbraut $90 \mathrm{~m}$ terrace (last superficial event; Figs 1,10), at Hólssandur (Kvensodull dunes) and at Dingjuvatn (close to the Askja), as also in surface the Krákárbotnar palaeofan (Bárðarbunga source). 
823

824

825

826

827

828

829

830

831

832

833

834

835

836

837

838

839

840

841

842

843

844

845

846

847

848

849

850

851

852

\subsection{Hypothetical mega-jökulhlaups}

The two potential mega-jökulhlaups were those (1) responsible for the limited Varghóll surge (South, ca. $11.5 \mathrm{cal} \mathrm{ka)} \mathrm{and} \mathrm{the} \mathrm{Hnausar} \mathrm{surge} \mathrm{and} \mathrm{bursting} \mathrm{(Jökulsá} \mathrm{á} \mathrm{Fjöllum;} \mathrm{ca.} 11.5 \mathrm{cal} \mathrm{ka)} \mathrm{and} \mathrm{(2)} \mathrm{the}$ "Hỏlssandur hydraulic dunes" event (Jökulsá á Fjöllum, Barðardalur, Pjorsá Rivers; ca 10.1-9.9 cal ka). These were of the rupture type, with a permafrost infiltrated terminal moraine.

Volcanic melt-induced floodwaters were likely rapidly transmitted down via fractures nets in the ice and the bedrock, with peak flooding lasting only for a few days (Björnsson, 1998). In the case of the climatic-melt-and-ice-rupture type, the lake discharge increased slowly to reach peak flow. Such floods are cold, dense and progressive (Snorrason et al. 1997; Flowers et al. 2003) in connection with climate warming. They probably took a much longer time to diminish, due to the more diffused geometry of the path of subglacial water migration. If a diffuse aquifer was formed, constrained by permafrost, the duration of the drainage might have been several weeks, limiting the size of the maximal outburst.

Evidence for large prehistoric peak discharges of $0.2-1.010^{6} \mathrm{~m}^{3} \mathrm{~s}^{-1}$ in the Jökulsá á Fjöllum Valley has been presented by Sæmundsson (1973), Tómasson (1973, 2002) and Waitt (2002), among others. For the upper valley, Alho et al. (2005) and Carrivick et al. (2013) estimated a maximal discharge of up to $0.910^{6} \mathrm{~m}^{3} \mathrm{~s}^{-1}$ along the entire Jökulsá á Fjöllum for the "9.3 cal ka" events. At the level of Hrossaborg, we obtained a peak discharge of $0.7110^{6} \mathrm{~m}^{3} \mathrm{~s}^{-1}$ to erode its top (50 m water depth) by using the flood-affected transverse profile of the valleys and the same flow speed (Alho et al. 2005: $2.0 \mathrm{~m} \mathrm{~s}^{-1}$ ). Modeling by Gylfadóttir et al. (2017) estimated a flood discharge of $0.110^{6} \mathrm{~m}^{3} \mathrm{~s}^{-1}$, for a flood level at the footh of the Hrossaborg. At the level of Hólssandur (Kvensodull, $10.1-9.9 \mathrm{cal}$ ka events), we obtained a peak discharge of $1.6510^{6} \mathrm{~m}^{3} \mathrm{~s}^{-1}$ with the present-day morphology, and 1.08 $10^{6} \mathrm{~m}^{3} \mathrm{~s}^{-1}$, assuming an infilled canyon to 200 masl (Hỏlmatungur-Vestudalur terrace). At Ásbyrgi, Waitt (2002) estimated it to be $0.710^{6} \mathrm{~m}^{3} \mathrm{~s}^{-1}$. Our observations give a similar value for an infilled canyon.

The Preboreal jökulhlaups in Iceland were not much bigger than the others, or for the Jökulsá Rivers, not largely exceeding a maximal volume of $110^{6} \mathrm{~m}^{3} \mathrm{~s}^{-1}$. This implies a limited significance for climate- 
driven meltwater storage in subglacial aquifers and lakes, and their specific drainage contributions, as also stressed for the recent warming (Flowers et al. 2003). Since the volume of the Bárðarbunga caldera is $3.610^{6} \mathrm{~m}^{3}$, the emptying of this basin is not sufficient to provide such a discharge for hours, but it obviously contributed to flood peaking. The volume of climate-driven meltwater has in turn impacted the loading / unloading of magmatic chambers to trigger eruptions, controlling the maximal discharge of floods obviously much less than do volcanogenic events. All volcanic / climatic combinations are possible, but during deglacial times, the duration of flood events was probably very long, of the order of a few months following the season. For these reasons, they seem less efficient as a bedrock erosion agent than commonly published. This is not true for soft sedimentary infillings.

The canyons incisions for the different outlets of the Vatanjökull result apparently from recurrent periods of activity throughout the Quaternary. This is shown by the preservation of the very old and/or last interglacial sediments close to the valleys bottoms. The excavation of the successive unconsolidated glacial infills, perhaps reached several times the basement during the early Holocene. The Bárðardalur sedimentary infilling was fully re-excavated before the Svartarvatn advance (ca 9.3 cal ka). The Jökulsá á Fjöllum valley already was deeply excavated prior to the re-infilling by the Preboreal advance (ca $11.3 \mathrm{cal} \mathrm{ka)}$; the last re-excavation started with the ca $9.9 \mathrm{cal}$ ka event, as probably also in the Bárðardalur. It corresponds to the largest splayed jökulhlaups in connection to the ca 9.9 cal ka major eruption of the Bárðarbunga Volcano (Guðmundsdóttir et al. 2016) and perhaps the emptying of the whole caldera: a profond channel scours the northern side of the caldera (Björnsson, 2017). The ${ }^{3} \mathrm{He}$ dating provided by Baynes et al. (2015) of the surface exposure of the terraces from the "9.9 cal ka" event represents the clearance by steps of the Jökulsá á Fjöllum valley. This erosion within the canyon is more efficient to incise the basement due to constricted floods.

\subsection{Generalisation}

The expected succession for deglacial events is not the systematic rule. A subglacial major eruption is rarely immediately followed by the formation of a large lake, a surging in form of jökulhlaup or glacial surge and a final emission of phreatomagmatic ash. Some steps are often missing or delayed in time. The Preboreal megafloods revealed in Iceland that climate-driven flood events from ice-cap internal storage are generaly long, with relatively limited discharges, but potentially large volumes. This can be 
compared to dam breakage as for the Missoula Lake (Wait, 1985) or for the Proglacial Lake in Altai (Rudoy et al, 1993). The piking of the flood discharge occurs as well with dam breakage as with subglacial eruption. Surging of glaciers is frequent today as in Preboreal times. These floods are generally associated with major deglaciation events, excepted when the subglacial volcanic activity is raised by a major glacio-isostatic unloading. Wide water lateral-splay are most probably linked to permafrost persistence in the valley and do not necessarily imply larger flood volumes.

The canyons incision are for a major part an inheritage of quaternary glaciations. This morphology is commonly recycled with recurrent glaciations, following the same flow lines. It has been also demonstrated for the ice-dammed Missoula Lake (Waitt, 1985; Clague et al. 2003). The erosion capability of megafloods have been exaggerated, even more efficient in constricted conditions. The youngest incision in glacigenic environment proceeds by clearance of the successive glacial pulse accompanying the deglaciation under control of the glacio-isostatic rebound. Only the full interglacial flows will incise efficiently the bedrock.

\section{Conclusions}

Deglaciation events are almost synchronic in Iceland with the surrounding north Atlantic regions, as far the accuracy of the dating may allow correlations; they are under control of the Irminger Sea Current. The Preboreal jökulhlaups in Iceland fully correlate with both the deglaciation events and the subglacial volcanic activity. This succession, initially triggered by climate change, and responsible for superficial melting and volcanic activity, led to cascading retroactive events. The succession occurred at least twice close to $11.5-11.3 \mathrm{cal}$ ka and around 10.3 to $10.1-9.9 \mathrm{cal}$ ka. Minor events existed during the Alleröd / Younger Dryas, and also probably occurred in association with the "9.3 cal ka" deglaciation, with an already restricted ice-cap mass. These Preboreal jökulhlaups were not much larger than the others, and never largely exceeded a flood of $110^{6} \mathrm{~m}^{3} \mathrm{~s}^{-1}$. They splayed on partially frozen ground with a limited incision capability, often driven to the East by the Coriolis forces. Ongoing glacial rebound to $10.3 \mathrm{cal}$ ka temporarily lowered the slopes of the valleys, limiting the clearance and incision of the canyons. The Saksunarvatn Tephra mostly marked the end of the main phase of deglaciation, at $10.3-9.9 \mathrm{cal} \mathrm{ka}$, in relation to the temperature rise to the thermal optimum. It also signaled the onset of interglacial activity for the Barðarbungá and Grímsvötn Volcanoes. These close interrelations between climate and volcanic activity for generating jökulhlaups of long duration during 
913

914

915

916

917

918

919

920

921

922

923

924

925

926

927

928

929

930

931

932

933

934

935

936

937

938

939

940

941

major deglaciations events can be easily applied to other volcanic englaciated regions such as Western Antarctica, Alaska or Oregon.

\section{ACKNOWLEDGEMENTS}

This study was funded by the French Polar Institute Paul-Emile Victor (IPEV), Arctic Research Program number 316 (ICPROCI I, II and III), which covered the fieldwork in Iceland. We especially thank - Kristjan Sæmundsson for providing the original dating for the Krafla caldera and - the Vatnajökull National Park to have allowed investigations and samplings in protected natural areas. We also thank the students Anne-Sophie Van Cauwenberge, Audrey Wayolle, and Guillaume Gosselin for their assistance during fieldwork in 2004,2006 , and 2008 . We also gratefully thank a reviewer for all his positive comments and suggestion of improvements.

\section{REFERENCES.}

Albino F, Pinel V, Sigmundsson F (2010) Influence of surface load variations on eruption likelihood: application to two Icelandic subglacial volcanoes, Grímsvötn and Katla. Geophys J Int 181:1510-1524. https://doi: 10.1111/j.1365-246X.2010.04603.x

Alho P (2003): Land cover characteristics in NE Iceland with special reference to jökulhlaup geomorphology. Geogr Ann A (3-4): 213-227.

Alho P, Roberts M, Käyhkö J (2007) Estimating the inundation area of a massive, hypothetical jökulhlaup from northwest Vatnajökull, Iceland. Natural Haz 41: 21-42.

Andrés N, Palacios D, Tanarro LM, Fernández JM (2016) The origin of glacial alpine landscape in Tröllaskagi peninsula (North Iceland). Cuadernos Invest. Geogr 42(2), 341-368. https://doi.org/10.18172/ cig.2935

Andrès N, Palacios D, Sæmundsson P, Brynjólfsson S, Fernández-Fernández JM (2019) The rapid deglaciation of the Skagafjörour fjord, northern Iceland. Boreas 48: 92-106. https://doi.org/10.1111/bor.12341. ISSN 0300-9483.

Andresen CS, Bjorck S, Bennike O, HeinemeierJ, Kromer B (2000) What do $\Delta^{14} \mathrm{C}$ changes across the Gerzensee oscillation/GI-1b event imply for deglacial oscillations J.Quat Sci , 15: 203-214. 
Andrews JT, Geirsdóttir Á, Principato S, Kristjánsdóttir GB, Helgadóttir G, Hardardóttir J, Grönvold K, Sveinbjörnsdóttir Á, Drexler J (2002) Distribution, age and geochemistry of the Saksunarvatn $10.18 \pm$ cal ka) ash in marine, lake, and terrestrial sediments, NW Iceland. J Quat Sci 17 (8), $731-745$

Baker, V.R. 1973. Palaeohydrology and sedimentology of Lake Missoula flooding in eastern Washington. Geol Soc Am.. Spec Paper, 144: 1-79.

Baynes ERC, Attal MI, Niedermann S, Kirstein LA, Dugmore AJ, Naylor M (2015) Erosion during extreme flood events dominates Holocene canyon evolution in northeast Iceland PNAS, 112: 2355-2360.

Benediktsson ÍÖ, Schomacker A, Johnson MD, Geiger AJ, Ingólfsson Ó, Guơmundsdóttir ER (2015) Architecture and structural evolution of an early Little Ice Age terminal moraine at the surgetype glacier Múlajökull, Iceland, J Geophys Res, Earth Surf., 120, 1895-1910. https://doi.org:10.1002/2015JF003514.

Benediktsson ÍÖ (2012) Polyphase structural evolution of a fine-grained, fold-dominated end moraine, Brúarjökull surge-type glacier, Iceland. Jökull, 62: 167-183.

Benn DI, Evans DJA (2011) Glaciers and Glaciation, Second edition. Hodder Education, London.

Benn DI, Fowler AC, Hewitt I, Sevestre H (2019); A general theory of glacier surges. J Glaciology 65, (253), 701-716. https://doi:10.1017/jog.2019.62

Birks H, Gulliksen S, Haflidalson H, Mangerud J et al. (1996) New Radiocarbon Dates for the Vedde Ash and the Saksunarvatn Ash from Western Norway. Quaternary Res 45:119-127.

Björck S, Rundgren M, Ingólfsson O, Funder S (1997) The Preboreal oscillation around the Nordic Seas: terrestrial and lacustrine responses. Quaternary Sci 12: 455-465.

Björnsson H (2017) The Glacier of Iceland, Translation of "Jöklar á Íslandi". 2009, Atlantis Press, Advances in Quaternary Sci.

Björnsson, H., 2002: Subglacial lakes and jökulhlaups in Iceland. Glob Planet Change, 35, 255-271.

Björnsson H (1998). Hydrological characteristics of the drainage system beneath a surging glacier. Nature, 395: 771-774.

Björnsson H (1992) Jökulhlaups in Iceland: prediction, characteristics and simulation. Ann. Glaciol., 16:95-106. 
971

Björnsson H (1974) Explanation of jökulhlaups from Grímsvötn, Vatnajökull, Iceland. Jökull, 24: 1-25.

Björnsson H., Pálsson, F, Sigurđsson, O., Flowers, GE (2003) Surges of glaciers in Iceland. Ann. Glaciology, 36: 82-90.

Bond GG., Kromer B, Beer J, Muscheler R, Evans M, Showers W. Hoffmann S. Lotti-Bond R, Hajdas I, Bonani G (2001) Persistent Solar influence on North Atlantic climate during the Holocene. Science, 294: 2130-2136.

Bos JAA, van Geel B, van der Plicht J, Bohncke SJP (2007) Preboreal climate oscillations in Europe: Wiggle-match dating and synthesis of Dutch high-resolution multi-proxy records. Quat Sci Rev, 26: 1927-1950.

Boulton GS, van der Meer JJM, Beets DJ, Hart J, Ruegg GH (1999) The sedimentary and structural evolution of a recent Push moraine complex: Óstrømbreen, Spitsbergen. Quat Sci Rev 18: 339-371.

Brader MD, Lloyd JM, Bentley MJ, Newton AJ (2015) Lateglacial to Holocene relative sea-level changes in the Stykkisholmur area, northern Snæfellsnes, Iceland.J Quat Sci., 30: 497-507.

Bronk RC, Albert PG, Blockley SPE, Hardiman M, Housley RA, Lane CS et al. (2015) Improved age estimates for key Late Quaternary European tephra horizons in the RESET lattice. Quat Sci Rev 118:18-32. https://doi.org/10.1016/j.quascirev.2014.11.007

Carling PA (2013) Fresh water megaflood sedimentation: what can we learn about generic processes. Earth Sci. Rev125: 87-113.

Carrivick JL (2007). Hydrodynamics and geomorphic work of jökulhlaups (glacial outburst floods) from Kverkfjöll volcano, Iceland. Hydrol Process 21: 725-740.

Carrivick JL, Tweed FS., Carling PA, Alho P, Marren PM, Staines K, Russell AJ, Rushmer EL, Duller R (2013) Discussion of field evidence and hydraulic modelling of a large Holocene jökulhlaup at Jökulsá á Fjöllum channel, Iceland' by Douglas Howard, Sheryl Luzzadder-Beach and Timothy Beach, 2012, Geomorphology, 201, 512-519

Carrivick JL, Russell AJ, Rushmer EL, Tweed FS, Marren PM, Deeming KR, Lowe HG (2009) Geomorphological evidence towards a de-glacial control on volcanism. Earth Surface. Process Landf 34: 1164-1178.

Clague JJ, Barendregt R; Enkin RJ, Foit FF (2003) Paleomagnetic and tephra evidence for tens of Missoula floods in southern Washington. Geology Geol Soc. Am 31: 247-250. 
1001

1002

1003

1004

1005

1006

1007

1008

1009

1010

1011

1012

1013

1014

1015

1016

1017

1018

1019

1020

1021

1022

1023

1024

1025

1026

1027

1028

1029

Condron A, Winsor P (2012). Meltwater routing and the Younger Dryas. Proc Natl Acad Sci U S., 109:19928-19933. https://doi:10.1073/pnas.1207381109.

Dahl-Jensen D. and NEEM community members (2013) Eemian interglacial reconstructed from a Greenland folded ice core. Nature, 493. 489-49.

Dahl SO, Nesje A, Lie O, Fjordheim K, Matthews JA (2002) Timing, equilibrium-line altitudes and climatic implications of two early-Holocene glacier readvances during the Erdalen Event at Jostedalsbreen, western Norway. Holocene 12:17-25.

Doyle S, Hubbard A, van de Wal R, Box J, van As D, Scharrer K, Meierbachtol T, Smeets, P, et al. (2015) Amplified melt and flow of the Greenland ice sheet driven by late-summer cyclonic rainfall. Nature Geo. 10.1038/NGEO2482.

Eason D, Sinton JM, Grönvold K., Kurz M (2015) Effects of deglaciation on the petrology and eruptive history of the Western Volcanic Zone, Iceland. B Volcanol 77: 47. https://doi10.1007/s00445015-0916-0

Eiríksson J, Knudsen KL, Haflidason H, Henriksen P (2000) Late-glacial and Holocene palaeoceanography of the North Icelandic shelf. J Quat Sci 15, 23-42.

Eksinchol I, Rudge JF, Maclennan J (2019) Rate of melt ascent beneath Iceland from the magmatic response to deglaciation. Geochem Geophy Geosy 20: 2585-2605.

Elíasson S (1977) Molar um Jökulsarhlaup og Asbyrgi. Natturufæjingurinn 47, 160-179.

Eyles N, Boyce Jl, Barendregt RW (1999) .Hummocky moraine: Sedimentary record of stagnant Laurentide Ice Sheet lobes resting on soft beds. Sediment Geol 123: 163-174. Https://doi.org:10.1016/S0037-0738(98)00129-8

Etzelmüller B, Farbrot H, Guormundsson Á, Humlum O, Tveito O., Björnsson H (2007). The regional distribution of mountain permafrost in Iceland. Permafrost Periglac 18: 185-199.

Fard AM (2002) Large dead-ice depressions in flat-topped eskers: evidence of a Preboreal jökulhlaup in the Stockholm area, Sweden. Glob Planet Change 35, 273-295

Fitzpatrick AAW., Hubbard AL, Box JE, Quincey DJ, van As D, Mikkelsen APB, Doyle SH, Dow CF, Hasholt B, Jones GA (2014) A decade (2002-2012) of supraglacial lake volume estimates across Russell Glacier, West Greenland. Cryosphere, 8, 107-121, https://doi.org/10.5194/tc-8107-2014, 2014. 
Flowers GE, Björnsson H, Pálsson F (2003) New insights into the subglacial and periglacial hydrology of Vatnajökull, Iceland, from a distributed physical model. J Glaciology, 49, 165,257-270.

GAPHAZ (2017) Assessment of Glacier and Permafrost Hazards in Mountain Regions - Technical Guidance Document. Prepared by Allen, S., Frey, H., Huggel, C. et al. Standing Group on Glacier and Permafrost Hazards in Mountains (GAPHAZ) of the IACS and IPA. Zurich, Switzerland / Lima, Peru.

Geirsdóttir Á, Eiríksson J (1996) A review of studies of the earliest glaciations in Iceland.Terra Nova 8: 400-414.

Geirsdóttir Á, Hardardóttir J, Sveinbjörnsdóttir ÁE (2000) Glacial extent and catastrophic meltwater events during the deglaciation of Southern Iceland .Quat Sci Rev 19: 1749-1761.

Geirsdóttir A., Miller GH, Axford Y, Olafsdóttir S (2009) Holocene and latest Pleistocene climate and glacier fluctuations in Iceland. Quat Sci.Rev 28 (21-22): 2107-2118.

Geirsdóttir Á, Miller GH, Larsen GJ, Ólafsdótti S (2013) Abrupt Holocene climate transitions in the northern North Atlantic region recorded by synchronized lacustrine records in Iceland. Quat Sci Rev 70 (15): 48-62.

Goslar T, Arnold M, Tisnerat-Laborde N, Czernik J, Wieckowski K (2000) Variations of Younger Dryas atmospheric radiocarbon explicable without ocean circulation changes. Nature 403: 877-880.

Grönvold K, Oskarsson N, Johnsen SJ, Clausen HB, Hammer CU, Bond G, Bard E (1995) Ash layers from Iceland in the Greenland GRIP ice core correlated with oceanic and land based sediments. Earth Planet Sci Lett 135, 149-155.

Guơmundsdóttir ER, Larsen GD, Björck S, Ingólfsson Ó, Striberger J (2016) A new high-resolution Holocene tephra stratigraphy in eastern Iceland: Improving the Icelandic and North Atlantic tephrochronology. Quat Sci Rev 150, 234-249. https://doi: 10.1016/j.quascirev.2016.08.011

Guơmundsdóttir ER, Larsen GD, Eiríksson J (2012) Tephra stratigraphy on the North Icelandic shelf: extending tephrochronology into marine sediments off North Iceland. Boreas, 41: 718-734.

Guð̌mundsson Á (2000) Frerafjöll, Urðarbingir á Tröllaskaga. MSc thesis, University of Iceland, Reykjavik, Iceland.

Guðmundsson MT, Sigmundsson F, Björnsson.H (1997) Ice - volcano interaction of the 1996 Gjálp subglacial eruption, Vatnajökull, Iceland.Nature,389( 6654): 954-957. 
1060

1061

1062

1063

1064

1065

1066

1067

1068

1069

1070

1071

1072

1073

1074

1075

1076

1077

1078

1079

1080

1081

1082

1083

1084

1085

1086

1087

1088

1089

Guormundsson MT, Björnsson H, Pálsson F (1995) Changes in jökulhlaup sizes in Grímsvötn, Vatnajökull, Iceland, 1934-91, deduced from in-situ measurements of subglacial lake volume. J.Glaciology, 41 (38): 263-272.

Gylfadóttir SS, PórarinsdóttirT, Pagneux E, Björnsson BB (2017) Hermun jökulhlaupa í Jökulsá á Fjöllum með GeoClaw. Icelandic Meteorologic Office, VÍ 2017-004, ISSN 1670-8261.

Haflidason H, Eiríksson J, Van Kreveld S (2000) The tephrochronology of Iceland and the North Atlantic region during the Middle and Late Quaternary: a review. J Quat Sci 15:3-22.

Halldórsson SA, Oskarsson N, Grönvold K, Sigurdsson G, Sverrisdóttir G, Steinthorsson S (2008) Isotopic heterogeneity of the Thjorsa lava - implications for mantle sources and crustal processes within the Eastern Rift Zone, Iceland. Chem Geol, 255, 1-3: 305-316.

Harning DJ, Geirsdóttir Á, Miller GH, Zalzal K (2016). Early Holocene deglaciation of Drangajökull, Vestfirðir, Iceland. Quat Sci Rev 153:192-198.

Hartley ME, ThordarsonT, de Joux A (2016) Postglacial eruptive history of the Askja region, North IcelandBull Volcanol 78: 28. https://doi.org/10.1007/s00445-016-1022-7.

Hjartardóttir ÁR, Einarsson P (2017) Eru Hljóðaklettar og Rauơhólar í Jökulsárgljúfrum gervigígar? Haustráðstefna Jarðfræðafélags Íslands 17: 7-8.

Hjartarson Á (2003) The Skagafjörður unconformity, north Iceland, and its geological history. PhD thesis, Geol. Museum, Univ Copenhagen.

Hoskuldsson A, Sparks RSJ, Carroll MR (2006) Constraints on the dynamics of subglacial basalt eruptions from geological and geochemical observations at Kverkfjoll, E Iceland. B Volcanol 68: 689-701. https://doi 10.1007/s00445-005-004 3-4.

ICS 2018. International commission for Stratigraphy - International chronostratigraphic chart v2018/07. http://www.stratigraphy.org/

Jennings A, Syvitski J, Gerson L, Grönvold K, Geirsdóttir Á, Hardardóttir J, Andrews J, Hagen S (2000) Chronology and paleoenvironments during the Late Weichselian deglaciation of the Southwest Iceland Shelf. Boreas 29: 167-183.

Jóhannsdóttir GE (2007) Mid-Holocene to late glacial tephrochronology in west Iceland as revealed in three lacustrine environments. MS thesis, Univ Iceland, Reykjavík.

Jonásson K (1994) Rhyolite volcanism in the Krafla central volcano, north-east Iceland. B Volcanol. $56: 516-528$. 
Jones G, Davies S, Farr G, Bevan J (2017) Identification of the Askja-S Tephra in a rare turlough record from Pant-y-Llyn, south Wales. Proc Geologists' Assoc 128 (4), 523-530. http://dx.doi.org/10.1016/j.pgeola.2017.05.010

Jull M, McKenzie D (1996) The effect of deglaciation on mantle melting beneath Iceland. J Geophys Res. 107: 21815-21828.

Kaldal I, Víkingsson S (1990) Early Holocene deglaciation in central Iceland. Jökull, 40, 51-66.

Kaldal I, Víkingsson S (2000). Jarơgrunnskort af Eyjabökkum. Orkustofnun report OS-2000/068. (Reykjavík, Iceland, 10 p.).

Kirkbride, M.P., Dugmore, A.J., Brazier, V. 2006. Radiocarbon dating of mid-Holocene megaflood deposits in the Jökulsá á Fjöllum, north Iceland. Holocene, 16 (4), 605-609.

Knudsen O (1995) Concertina eskers, Brúarjökull, Iceland: An indicator of surge-type glacier behaviour, December 1995. Quat Sci Rev 14:487-493. https://doi.org10.1016/02773791(95)00018-K.

Knudsen O, Marren PM 2002. Sedimentation in a volcanically dammed valley, Brúarjökull, Quat Sci Rev 21:1677-1692. https://doi10.1016/S0277-3791(01)00144-5.

Klingbjer P (2004) Recurring Jökulhlaups in Sälka, Northern Sweden. Geogr Ann A. Physic.Geogr, 86 (2), 169-179.

Kobashi T, Menviel L, Jeltsch-Thömmes A, Vinther BM, Box JE, Muscheler R., et al. (2017) Volcanic influence on centennial to millennial Holocene Greenland temperature change. Nature, Scient.Rep 7, 1441. https://doi.org: 10.1038/s41598-017-01451-7.

Koren H, Svendsen JI, Mangerud J, Furnes H (2008) The Dimna Ash — a $12.814 \mathrm{C}$ ka-old volcanic ash in Western Norway. Quat Sci Rev, 27: 85-94.

Lacasse C, Carey S, Sigurdsson H (1998) Volcanogenic sedimentation in the Iceland Basin: influence of subaerial and subglacial eruptions J Volcanol Geotherm Res 83: 47-73.

Langdon PG, Leng MJ, Holmes N, Caseldine CJ (2010) Lacustrine evidence of early-Holocene environmental change in northern Iceland: a multiproxy palaeoecologyand stable isotope study. Holocene 20: 205-214.

Larsen DJ, Mille GH, Geirsdóttir A, Olafsdóttir S (2012) Non-linear Holocene climate evolution in the North Atlantic: a high-resolution, multi-proxy record of glacier activity and environmental change from Hvítarvatn, central Iceland. Quat Sci. Rev 39: 14-25. 
1120

1121

1122

1123

1124

1125

1126

1127

1128

1129

1130

1131

1132

1133

1134

1135

1136

1137

1138

1139

1140

1141

1142

1143

1144

1145

1146

1147

1148

Larsen G, Eiríksson J (2007) Late Quaternary terrestrial tephrochronology of Iceland, frequency of explosive eruptions, type and volume of tephra deposits. J Quat Sci, 23:109-120. https://doi.org/10.1002/jqs.1129

Larsen G, Eiríksson J, Knudsen KL, Heinemeier J (2002) Correlation of late Holocene terrestrial and marine tephra markers in North Iceland. Implications for reservoir age changes and linking land-sea chronologies in the northern North Atlantic. Polar Res 21, 283-290.

Le Breton E, Dauteuil O, Biessy G (2010) Post-glacial rebound of Iceland during the Holocene. J Geol Soc., London, 167, 417-432. https://doi.org: 10.1144/0016-76492008-126.417.

Licciardi JM, Kurz MD, Curtice JM (2007) Glacial and volcanic history of Icelandic table -mountains from cosmogenic ${ }^{3} \mathrm{He}$ exposure ages. Quat Sci Rev 6:1529-1546. https://doi.org 10.1016/j.epsl.2006.03.016

Lind E, Wastegård S (2011) Tephra horizons contemporary with short early Holocene climate fluctuations: New results from the Faroe Islands. Quaternary Intern, 246: 157-167.

Lønne I (2016) A new concept for glacial geological investigations of surges, based on High-Arctic $\begin{array}{llllll}\text { examples (Svalbard), } & \text { Quat } & \text { Sci } & \text { Rev 132: 74-100. https://doi: }\end{array}$ 10.1016/j.quascirev.2015.11.0090.

Maclennan J, Jull M, McKenzie D, Slater L, Grönvold K (2002) The link between volcanism and deglaciation in Iceland. Geochem Geophy Geosy 3, 1062. https://doi:10.1029/2001GC000282

Maizels J (1997) Jökulhlaup deposits in proglacial areas. Quat Sci Rev 16:793-819.

Maizels J (1991) The origin and evolution of Holocene sandur deposits in areas of jökulhlaup drainage, Iceland. In: Maizels J, Caseldine C, Eds., Environmental Change in Iceland: Past and Present. Kluwer Academic Publ, Dordrecht, 267-279.

Maizels JK, Russell AJ (1992) Quaternary perspectives on jökulhlaup prediction, in Gray, J. M. (ed.) Applications of Quaternary Research, Quaternary Proceed, 2: 133-153.

Mangerud J, Furnes H, Johansen J (1986). A 9000 year ash bed on the Faroe Islands. Quaternary Res.26, 262-265.

Matero SO, Gregoire LJ, Ivanovic RF, Tindall JC, Haywood AM (2017) The 8.2 ka cooling event caused by Laurentide ice saddle collapse. Earth Planet Sci Lett 473: 205-214. https://doi.org/10.1016/j.epsl.2017.06.011 
1149

1150

1151

1152

1153

1154

1155

1156

1157

1158

1159

1160

1161

1162

1163

1164

1165

1166

1167

1168

1169

1170

1171

1172

1173

1174

1175

1176

1177

1178

Matthews JA, Shakesby RA, Schnabel C, Freeman S (2008) Cosmogenic ${ }^{10} \mathrm{Be}$ and ${ }^{26} \mathrm{Al}$ ages of Holocene moraines in southern Norway I: testing the method and confirmation of the date of the Erdalen Event (c. $10 \mathrm{ka}$ ) at its type-site. Holocene, 18:1155-1164. https://doi.org.org/10.1177/0959683608096585

Meier MF, Post AS (1969) What are glacier surges? Can.J Earth Sci. 6, 807-817.

Mikkelsen AB, Hubbard A, MacFerrin M, Box JE, Doyle S, Fitzpatrick A., Hasholt B, Bailey HL, Lindbäck K, Pettersson R (2016) Extraordinary runoff from the Greenland ice sheet in 2012 amplified by hypsometry and depleted firn retention. Cryosphere 10, 1147-1159.

Möller R, Möller M, Björnsson H., Guơmundsson S, Pálsson F, Oddsson B, Kukla P. Schneider C (2013) MODIS-derived albedo changes of Vatnajökull (Iceland) due to tephra deposition from the 2004 Grímsvötn eruption. Int J Appl Earth Obs 2:, 256-269.

Norðdahl H, Ingólfsson O, Vogler ED, Steingrímsson BO, Hjartarson Á (2019) Glacio-isostatic age modelling and Late Weichselian deglaciation of the Lögurinn basin, East Iceland. Boreas, 41: 563-580. https://doi.org/10.1111/bor.12366

NGRIP members (2004) High-resolution record of Northern Hemisphere climate extending into the last interglacial period. Nature 431: 147-151.

Óladóttir BA, Sigmarsson O, Larsen G, Devidal J-L (2011a) Provenance of basaltic tephras from Vatnajökull subglacial volcanoes, Iceland as determined by major- and trace-element analyses. Holocene, 21: 1037-1048.

Óladóttir BA, Larsen G, Sigmarsson O (2011b) Holocene volcanic activity at Grímsvötn, Bárdarbunga and Kverkfjöll subglacial centres beneath Vatnajökull, Iceland. B Volcanol, 7: 1187-1208

Olszewski A, Weckwerth P (1999) The morphogenesis of kettles in the Höfoabrekkujökull forefield, Mýrdalssandur, Iceland, Jökull, 47: 7188.

Ott F, Wulf S, Serb J, Słowiński M, Obremska M, Tjallingii R, Błaszkiewicz M, Brauer A (2016) Constraining the time span between the Early Holocene Hässeldalen and Askja-S Tephras through varve counting in the Lake Czechowskie sediment record, Poland. J Quat Sci 31:103113https://doi.org/10.1002/jqs.2844

Pagli C, Sigmundsson F, Pedersen R, Einarsson P, Arnadóttir T, Feigl KL (2007) Crustal deformation associated with the 1996 Gjalp subglacial eruption, Iceland: InSAR studies in affected areas adjacent to the Vatnajökull ice cap. Earth Planet Sci Lett 259: 24-33. 
1179

1180

1181

1182

1183

1184

1185

1186

1187

1188

1189

1190

1191

1192

1193

1194

1195

1196

1197

1198

1199

1200

1201

1202

1203

1204

1205

1206

1207

Pagli C, Sigmundsson F (2008) Will present day glacier retreat increase volcanic activity? Stress induced by recent glacier retreat and its effect on magmatism at the Vatnajökull ice cap, Iceland. Geophys Res Lett 35: L09304.

Patton H., Hubbard A., Bradwell, T., Schomacker A. 2017. The configuration, sensitivity and rapid retreat of the Late Weichselian Icelandic ice sheet. Earth Sci Rev 166: 223-245.

Rasmussen SO, Andersen KK, Svensson AM, Steffensen JP., Vinther, B, Clausen HB et al. (2006) A new Greenland ice core chronology for the last glacial termination. J.Geophys Res.111, 1-15.

Rasmussen TL, Wastegard S, Kuijpers A, van Weering TCE, Heinemeier J, Thomsen E (2003) Stratigraphy and distribution of tephra layers in marine sediment cores from the Faroe Islands, North Atlantic. Marine Geol. 199, 263-277.

Rasmussen TL, Thomsen E, Nielsen T, Wastegård S (2011) Atlantic surface water inflow to the Nordic seas during the Pleistocene-Holocene transition (mid-late Younger Dryas and Pre-Boreal periods, 12 450-10 000 a BP) J. Quat Sci. 26: 723-733,

Rasmussen SO, Bigler M, Blockley SP, Blunier T, Buchardt SL, Clausen HB., et al. (2014) Stratigraphic framework for abrupt climatic changes during the Last Glacial period based on three synchronized Greenland ice-core records: Refining and extending the INTIMATE event stratigraphy. Quat Sci Rev 106:14-28.

Roberts MJ, Russell AJ, Tweed FS, Knudsen Ó (2000) Ice fracturing during Jokulhlaups: Implications for englacial floodwater routing and outlet development. Earth Surf Process Landf 25: 14291446. Https://doi.org10.1002/1096-9837(200012)25.

Roberts MJ, Tweed FS, Russell AJ, Knudsen O, Harris TD (2003) Hydrologic and geomorphic effects of temporary ice dammed lake formation during jökulhlaups. Earth Surf Process Landf 28: 723-737.

Rudoy AN, Baker VR (1993) Sedimentary effects of cataclysmic late Pleistocene glacial outburst flooding, Altay Mountains, Siberia. Sediment Geol. 85: 53-62.

Rushmer EL (2006) Sedimentological and geomorphological impacts of the jökulhlaup (glacial outburst flood) in January 2002 at Kverkfjöll, northern Iceland. Geogr Ann A:1-11.

Russell AJ (1993) Supraglacial lake drainage near Søndre Strømfjord, Greenland. J Glaciology 39: $431-433$ 
Russell AJ, Knight PG, Van Dijk TAGP (2001) Glacier surging as a control on the development of proglacial, fluvial landforms and deposits, Skeidararsandur, Iceland. Glob Planet Change 28:163-174..

Russell AJ, Knudsen Ó (1999) An ice-contact rhythmite (turbidite) succession deposited during the November 1996 catastrophic outburst flood (jökulhlaup), Skeiðarárjökull, Iceland. Sediment Geol 127(1-2): 1-10.

Russell AJ, Marren PM (1998). Younger Dryas (Loch Lomond Stadial) jökulhlaup deposits, Fort Augustus, Scotland. Boreas 27: 231-242.

Russell AJ, Tweed FS, Knudsen O, Roberts MJ., Harris TD, Marren PM (2002) Impact of the July 1999 jökulhlaup on the proximal river Jökulsa a Solheimasandi, Myrdalsjökull glacier, southern Iceland. IAHS Publ. Nr 271, Reykjavik: 249-254.

Sæmundsson K.(1991) Geology of the Krafla system. In: Gardarsson A, Einarsson A (editors) Nfitttira Myvatns. Hid Islenska Nattirufraedif 61ag, Reykjav N: 25-95.

Sæmundsson K. (1973) Straumraðkajar klappir I' kringum Asbyrgi.Natturufæjingurinn 43: 52-60.

Sæmundsson K, Hjartarson Á, Kaldal I, Sigurgeirsson MÁ., Kristinsson SG, Víkingsson S (2012) Geological Map of the Northern Volcanic Zone, Iceland. Northern Part. 1:100,000 (Iceland GeoSurvey, Reykjavik, Iceland).

Schomacker A, Benediktsson IO, Ingólfsson O (2014) The Eyjabakkajökull glacial landsystem, Iceland: Geomorphic impact of multiple surges Geomorphology, 218, 98-107. Https://doi.org: 10.1016/j.geomorph.2013.07.005

Sharp M, (1985) Sedimentation and stratigraphy at Eyjabakkajökull — an Icelandic surging glacier. Quaternary Res 24: 268-284.

Sigurðsson H. and Sparks RSJ (1978) Rifting episode in North Iceland in 1874-1875 and the eruptions of Askja and Sveinagjá. B Volcanol 41.149-167.

Sigurgeirsson, M. Á., 2016. Eldar í Öskjukerfi fyrir um 11 púsund árum (Volcanic episode in the Askja volcanic system 11.000 years ago), Náttúrufræðingurinn, 86 (3-4), 76-90.

Sigurgeirsson MÁ., Hjartarson Á., Kaldal I, Sæmundsson K, Kristinsson GS, Víkingsson S (2015) Geological Map of the Northern Volcanic Zone, Iceland. Southern Part. 1:100 000. Reykjavík: Iceland GeoSurvey. 
Sinton J, Grönvold K, Sæmundsson K (2005) Postglacial eruptive history of the Western Volcanic Zone, Iceland. Geochem Geophy Geosy 6,12. https://doi.org/10.1029/2005GC001021

Slater L, Jull M, McKenzie D, Grönvold K (1998). Deglaciation effects on mantle melting under Iceland: Results from the northern volcanic zone. Earth Planet. Sci Letters Lett. 164:151-154.

Smellie JL (2008) Basaltic subglacial sheet-like sequences: evidence for two types with different implications for the inferred thickness of associated ice. Earth Sci Rev 88: 60-88.

Snorrason A, Jónsson P, Pálsson S, Àrnason S, Sigurðsson O, Vikingsson S, Sigurðsson À, Zóphóniasson S (1997) The jökulhlaup in Skeiðarärsandur in the fall of 1996-extent of inundation, discharge and sediment transport) (in Icelandic). In: Vatnajökull—Gos og Hlaup 1996 (Vatnajökull eruption and jökulhlaup 1996) (ed. by II. Haraldsson), 79-137. The Icelandic Public Road Admin., Reykjavik, Iceland.

Striberger S, Björck S, Holmgren L, Hamerlik L (2012) The sediments of Lake Lögurinn - a unique proxy record of Holocene glacial meltwater variability in eastern Iceland. Quat Sci Rev 38: 7688.

Striberge J, Björck S, Benediktsson íÖ., Snowball I, Uvo CB, Ingólfsson Ó, Kjær KH (2011) Climatic control of the surge periodicity of an Icelandic outlet glacier. J Quat Sci 26: 561-565.

Stuiver M, Reimer PJ, Braziunas TF. (1998) High-precision radiocarbon age calibration for terrestrial and marine samples. Radiocarbon, 40, 3: 1127-1151]

Stuiver M, Braziunas TF (1989) Atmospheric 14C and Century-Scale Solar Oscillations. Nature, 338, 1041-1083. http://dx.Doi.org/10.1038/338405a0

Sund M, Eiken T, Hagen JO, Kääb A (2009) Svalbard surge dynamics derived from geometric changes. Ann Glaciol 50 (52): 50-60.

Thorarinsson S (1969) Glacier surges in Iceland with special reference to the surges of Bruarjokull. Can J Earth Sci, 6(4), Part 2: 875-882.

Thordarson T (2014) The widespread 10ka Saksunarvatn tephra is not a product single eruption American Geophysical Union, Fall Meeting 2014, abstract V24B-04612.

Tómasson H (1973) Hamfarahlaup i Jökulsá a Fjöllum. Náttúrufraiding urinn 43: 12-34.

Tweed FS (2000). Jökulhlaup initiation by ice-dam flotation: the significance of glacier debris content. Earth Surf Process Landf 25: 105-108. 
Van Vliet-Lanoë B, Bergerat F, Allemand P, Innocent C, Guillou H, Cavailhes T, Guð̌mundsson Á, Chazot G, Schneider JL, Grandjean P, Liorzou C, Passot S (2019) Tectonism and volcanism enhanced by deglaciation events in southern Iceland. Quaternary Res https://doi.org/10.1017/qua.2019.68.

Van Vliet-Lanoë B, Schneider JL, Guðmundsson Á, Guillou H, Nomade S, Chazot G, Liorziou C, Guégan S (2018) Eemian estuarine record forced by glacio-isostasy (S Iceland) - link with Greenland and deep sea records. Can J Earth Sc 55 (2): 154-171. Https:// 10.1139/cjes-20170126.

Van Vliet-Lanoë B, Pissart A, Baize S, Brulhet J, Ego E (2019) Evidence of multiple thermokarst events in northeastern France and southern Belgium during the two last glaciations. A discussion on 'Features caused by ground ice growth and decay in Late Pleistocene fluvial deposits, Paris basin, France' (Bertran et al. 2018). Geomorphology 327: 613-628. https://doi.org: GEOMOR-06499.

Van Vliet-Lanoë B, Guơmundsson Á, Guillou H, Duncan RA, Genty D, Ghaleb B, Gouy S, Récourt P, Scaillet S (2007) Limited glaciation and very early deglaciation in central Iceland: Implications for climate change. CR Geoscience, 339, 1-12.

Van Vliet-Lanoë B, Bourgeois O, Dauteuil O, Embry JC, Guillou H, Schneider JL (2005) Deglaciation and volcano-seismic activity in Northern Iceland: Holocene and Early Eemian (The Syðra Formation). Geodin Acta 18: 81-100.

Van Vliet-Lanoë B, Guðmundsson Á, Guillou H, van Loon AJ, De Vleeschouwer F (2010) Glacial Terminations II and I as recorded in NE Iceland. Geologos 16: 201-223.

Van Vliet-Lanoë B, Van Cauwenberge AS, Bourgeois O., Dauteuil O, Schneider JL (2001) A candidate for The Last Interglacial record in northern Iceland: the Syora Formation. Stratigraphy and sedimentology. C R Geoscience, 332:577-584.

Voelker AHL, Haflidason H (2015) Refining the Icelandic tephrachronology of the last glacial period The deep-sea core PS2644 record from the southern Greenland Sea. Glob Planet Change 131: $35-62$.

Vogfjörd KS, Jakobsdóttir SS, Guðrmundsson GB, Roberts MJ, Agustsson K, Arason T, et al. (2005) Forecasting and monitoring a subglacial eruption in Iceland. EOS 86:245-248. 
Vonmoos M, Beer J, Muscheler R (2006) Large variations in Holocene solar activity: Constraints from 10Be in the Greenland Ice Core Project ice core. J Geoph Res 111: A10105. Https://doi.org: 10.1029/2005JA011500.

Waitt RB (2002). Great Holocene floods along Jökulsá á Fjöllum, north Iceland. In: Martini P.I., Baker V.R., Garzón G. (Eds.), Flood and Megaflood Processes and Deposits: Recent and Ancient Examples. Spec Publ Int Ass Sedimentol 32, 37-51.

Waitt RB (1985) Case for periodic, colossal jökulhlaups from Pleistocene glacial Lake Missoula. Geol Soc Am Bull. 96 (10): 1271-1286.

Waller RI, Murton JB, Kristensen L (2012) Glacier-permafrost interactions: Processes, products and glaciological implications. Sed Geol 255-256:1-28. https://Doi: 10.1016/j.sedgeo.2012.02.005

Wohlfarth B, Blaauw M, Daviess SM, Andersson M, Wastegård S, Hormes A, Possnert G (2006) Constraining the age of Lateglacial and early Holocene pollen zones and tephra horizons in southern Sweden with Bayesian probability methods. J Quarternary Sci 21: 321-334. https://doi.org:10.1002/jqs.996.

Wylie J, Voight B, Whitehead J (2000). Instability of magma flow from volatile-dependant viscosity. Science 285: 1883-1885.

\section{FIGURES CAPTIONS}

Figure 1: A) Early Holocene jökulhlaup trajectories mapped with field observations and photographic interpretation. B) Cartographic illustration of the deglaciation history of Iceland, based on Kaldal and Víkingsson (1990) and recent geological maps (Sæmundsson et al. 2012; Sigurgeirsson et al. 2015), complemented by new photographic and/or field observations, tephrostratigraphy and correlations explained in the text.

Figure 2 Map of the maximal extent (Early Holocene) of floods in A) the Skjálfandafljót and B) the Jökulsá á Fjöllum Rivers. Light blue corresponds to the mapped largest flood extent, probably 
9.9 cal ka. Dark blue corresponds to the Late Holocene jökulhlaup pathways. Present-day glacial limits. Explanations and dating in § 4 Data.

Figure 3: Chronology of the recorded tephra and potential floods in relation to climate, 8-15 ka BP: potential impact of deglaciation induced by climate warming. Arrows - potential jökulhlaup events; SKA - Skjálfandafljöt River; JF - Jökulsá á Fjöllum River; SDJ - Skeiðararjökull Glacier, BRU: Jökulsá á Brú

A) Warming potentially linked to solar activity, derived from $\delta^{14} \mathrm{C}$ (Stuiver and Braziunas, 1988). Entire Saksunarvatn Tephra record from the literature shown in grey.

B) Regional mean temperatures from the NGRIP $\delta^{18} \mathrm{O}$ isotope curve (NGRIP, 2004). For tephra sources, see Table 1; SAKS - range of the Saksunarvatn event.

Tephra from Grimsvötn Volcano in black; Bárðarbunga Volcano in red; tephra from Askja Volcano in white, other rhyolitic tephra in yellow. The position of glacial advances are shown in blue. PBE-Preboreal cooling event; AL- Alleröd; ACE- Alleröd cooling event; BCE- Bölling cooling event.

Figure 4: map of the largest floods and morainic arc (partly eroded) preserved in the lower Jökulsá á Fjöllum.

Figure 5. Hnausar.(images from Google Earth [GE]). A) Deglaciation paleolake. B) Glacial surge (11.2 cal ka). C) Piercing by jökulhlaup. D) Tephrostratigraphic record.

Figure 6: Evidence of jökulhlaups in the Hólssandur Plateau at $380 \mathrm{~m}$ (images GE). A) Large, flat lozenge-shaped hydraulic dune at Kvensöðull. B) Details of the dunes, showing evidence of surface megaripples, and terrace levels from the end of the flood. C) Evidence south of $A$ of a residual terminal moraine and cinder cones, to the west, both eroded by floods, Note s, eroded by floods.

Figure 7: Evidence of terminal moraines on the Jökulsá á Fjöllum and Pjórsá-Tungnaá Rivers. North is upwards. A) Relict of a terminal moraine, SW of the Hrossaborg, eroded by floods - the 
Hrossaborg Advance, c. 10.3 cal ka (image Landmælingar Island [Lmls]). B) Terminal moraine that was issued from the Bruarjokul outlet glacier, NE of the Vaðalda - the Kreppa Advance, c. 9.3 cal ka pierced by jökulhlaup (image from LmIs). C) Kisa Advance, c. 9.3 cal ka, overlapped in the east by the Pjórsá Lava (8.7 cal ka; image Lmls ). D) Megaripples in basaltic sands (25 $\mathrm{m}$ wide) at the SW foot of the Vadalda Volcano (Sample Dingjuvatn D3; image LmIs). The North is upward.

Figure 8: Paths of the early Holocene jökulhlaup in the Skalfandafljót, Fnjoskadalur and Eyafjörður. Notice the location of disrupted glacial tongue that hypothetically (?) also reached the lower Skalfandafljót, but have been now eroded.

Figure 9: Ljósavatn and Halslón records. A-B) Ljósavatn pitted moraine. Evidence of jökulhlaup deposits, with iceberg kettle hole in juxtaglacial position The final infilling reworks an Askja tephra much older than the Askja S (Askja PB), Stórutjarnaskóli Quarry. B) Loess section above the Preboreal tillite; the Askja PB is involved with the loadcatsing in the grey loess. C-DE: Upper Hálslón Lake record. C) Deglacial braided sandur, reworking the Askja E Tephra; D) Twinned Saksunarvatn Tephra deposits in juxtaglacial position, deformed by late, but limited, glaciotectonics. E) Undeformed Saksunarvatn Tephra, buried by jökulhlaup deposits and loess in a lateral valley (Van Vliet-Lanoë et al. 2010).

Figure 10: Composite record of main sections, with reference to the main sources of tephra. JL jökulhlaup deposits, Gl - tillite. Iceberg scours at Varghóll and iceberg thermokarst at Ljósavatn. Classic thermokast (kettle hole) at Palmholt. Sections are located on figures 2-4-910.

Figure 11: A, B) Detail of the $\mathrm{N}$ moraine of the Eyjabakkajökull Glacier (images LmIs), the thick white arrow indicate 1890 stacked "push" moraines following Schomaker et al. 2014). C) Potential evidence of stacked, permafrosted moraines (Hólssandur). D) Stacked, permafrosted moraine, Usherbreen Glacier, Svalbard (image courtesy of J.O. Hagen). 
1383

Figure 12: The South-West A) Esker at Búðarháls, eroded by a jökulhlaup. B-D) Varghóll section, with terminal ridges (thick arrows on C; images Lmls), iceberg scours (B) incising a basaltic tephra deposit containing Vedde Ash pellets (stars), and a tillite stacking pattern (D).

Figure 13: Routes (black) of the early jökulhlaups in relation to the Holocene glacial advances (10.3 ka - white, $9.3 \mathrm{ka}$ - yellow). Potential subglacial lake / aquifers extents are shown in blue, related to a $125 \mathrm{~m}$ and $250 \mathrm{~m}$ residual glacio-isostatic subsidence. Black stippled line - present-day glaciers, white stippled line -10.3 cal ka glaciers

Table 1: Chronology of the significant eruptions of Grímsvötn, Bárðarbunga, Askja, Katla and Krafla volcanoes from Late Glacial to $8.2 \mathrm{cal}$ ka.

Table 2: Geochemical analysis of the tephra (ICPMS AES and * microprobe average; Microprobe on Supplement table 1)

\section{Supplement available on}

https://static-content.springer.com/esm/art\%3A10.1007\%2Fs00531-020-01833-

9/MediaObjects/531_2020_1833_MOESM1_ESM.pdf 

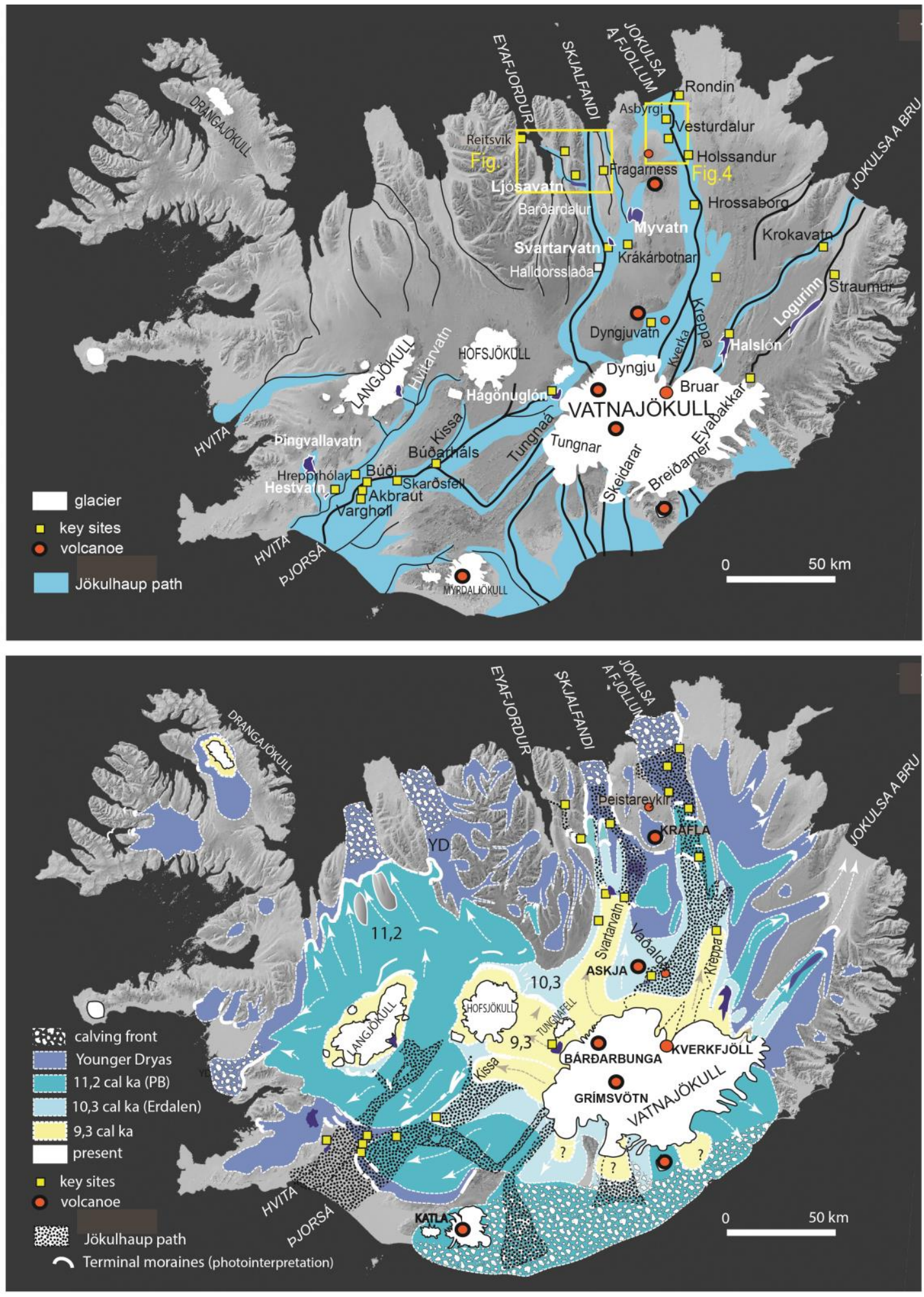


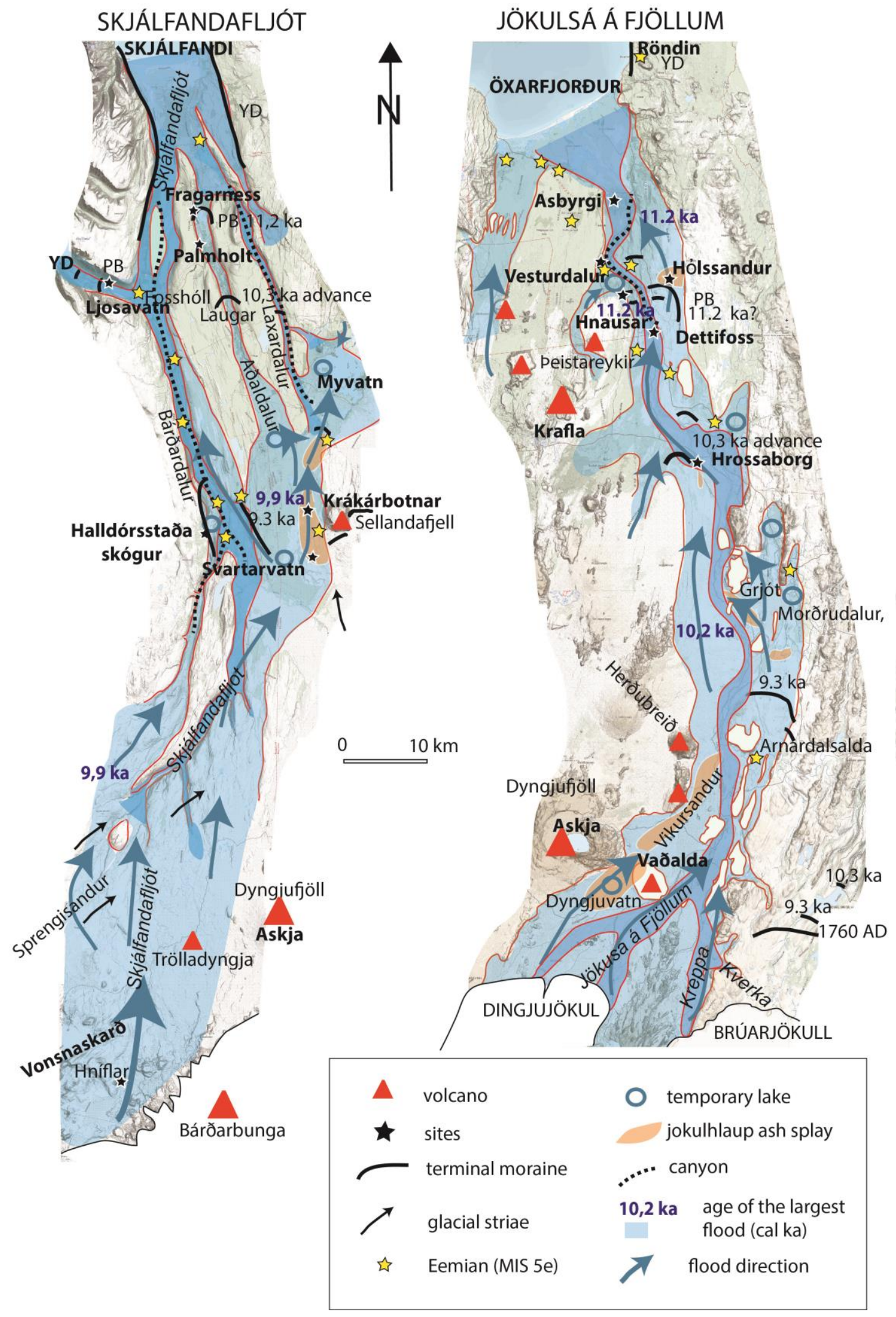



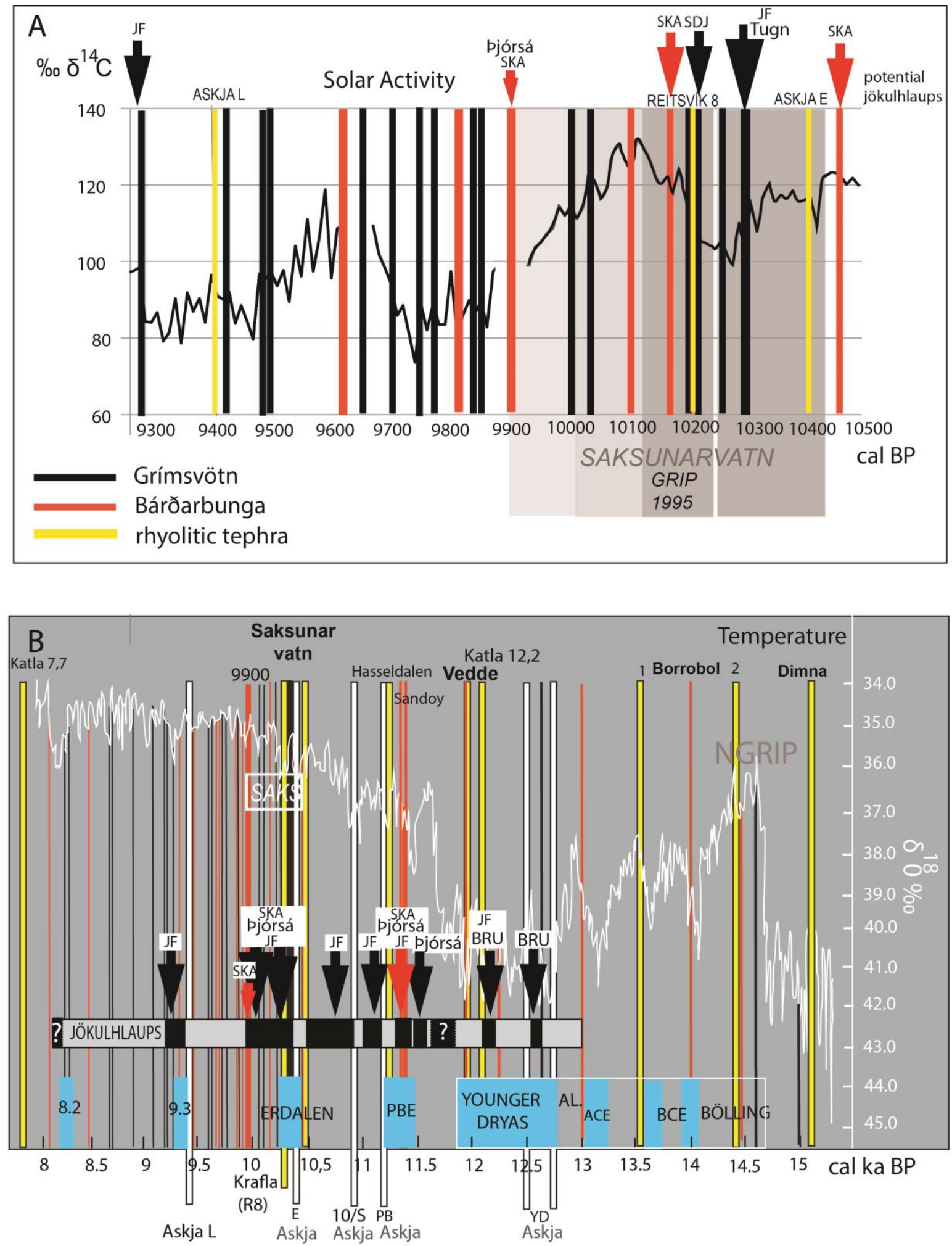


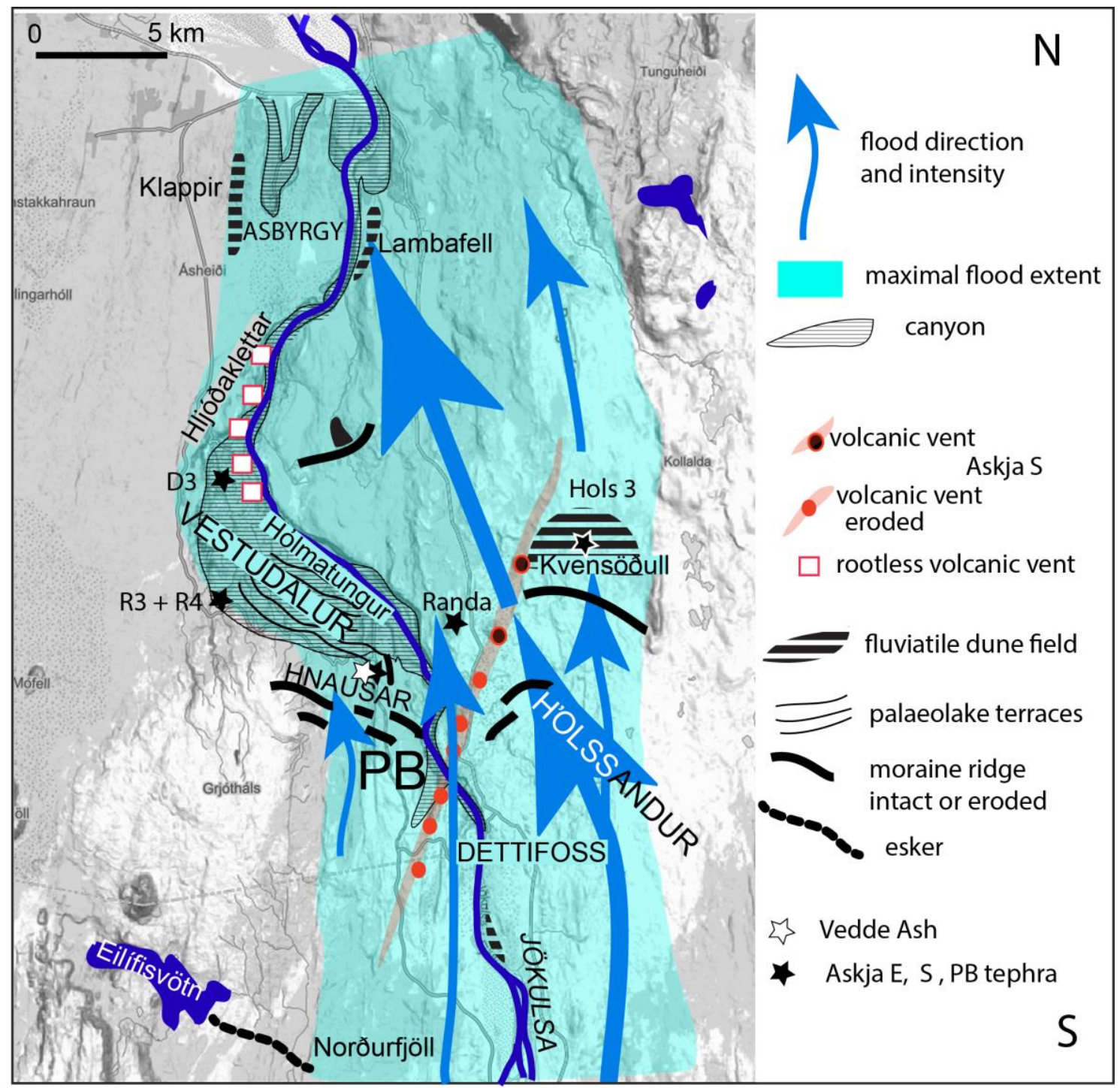



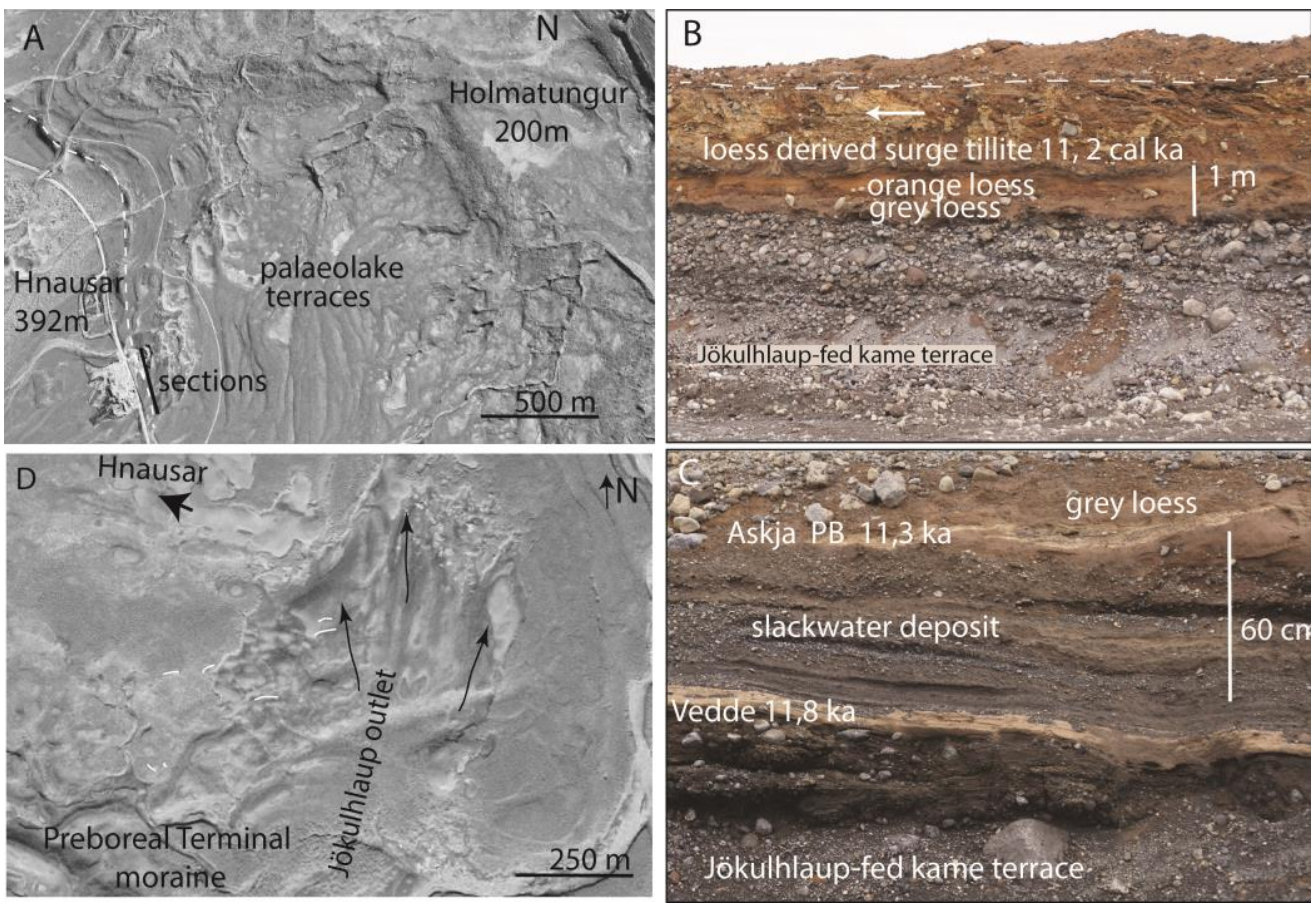

Fig.5
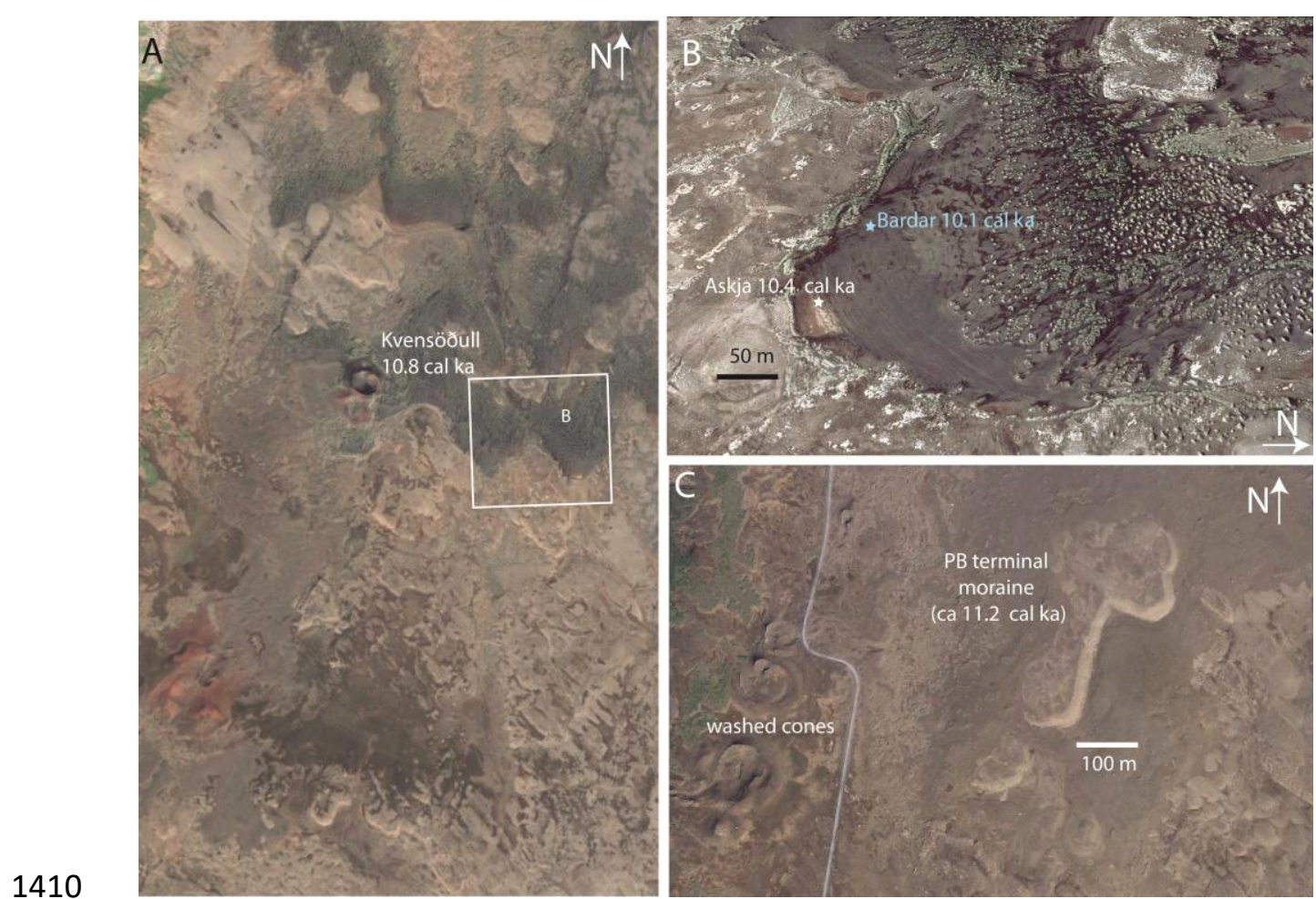

1411

Fig.6 

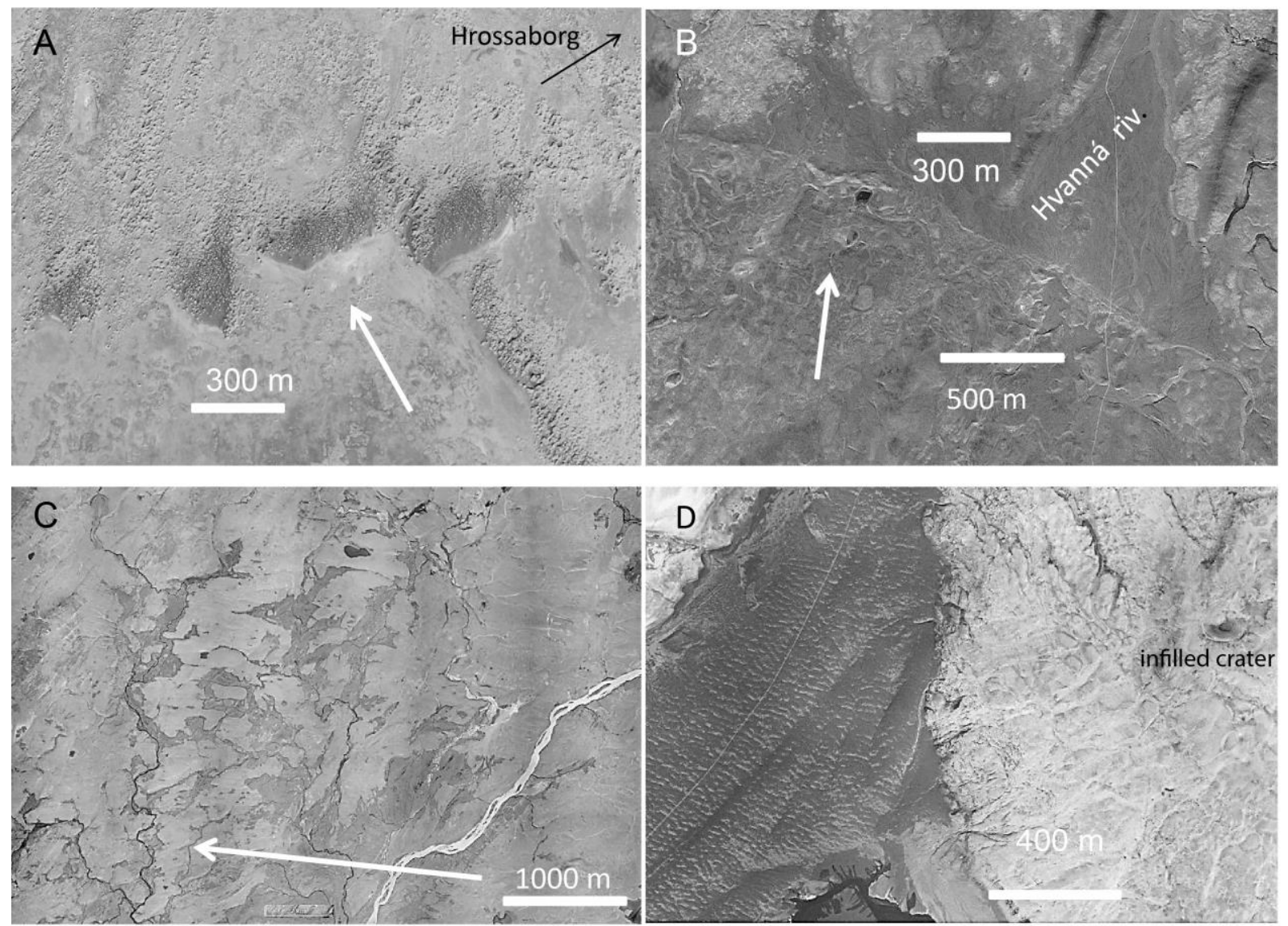

$1413 \quad$ Fig.7

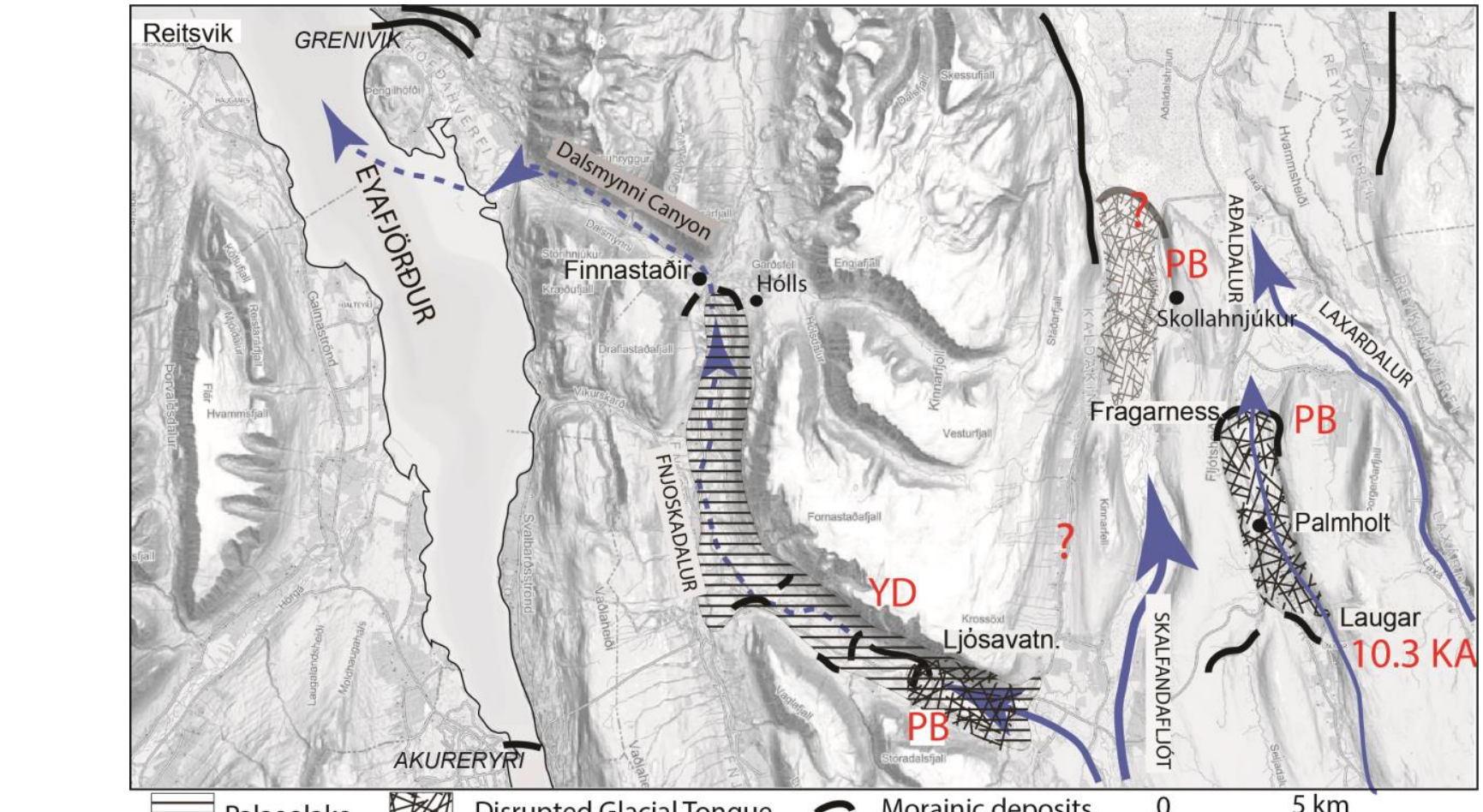



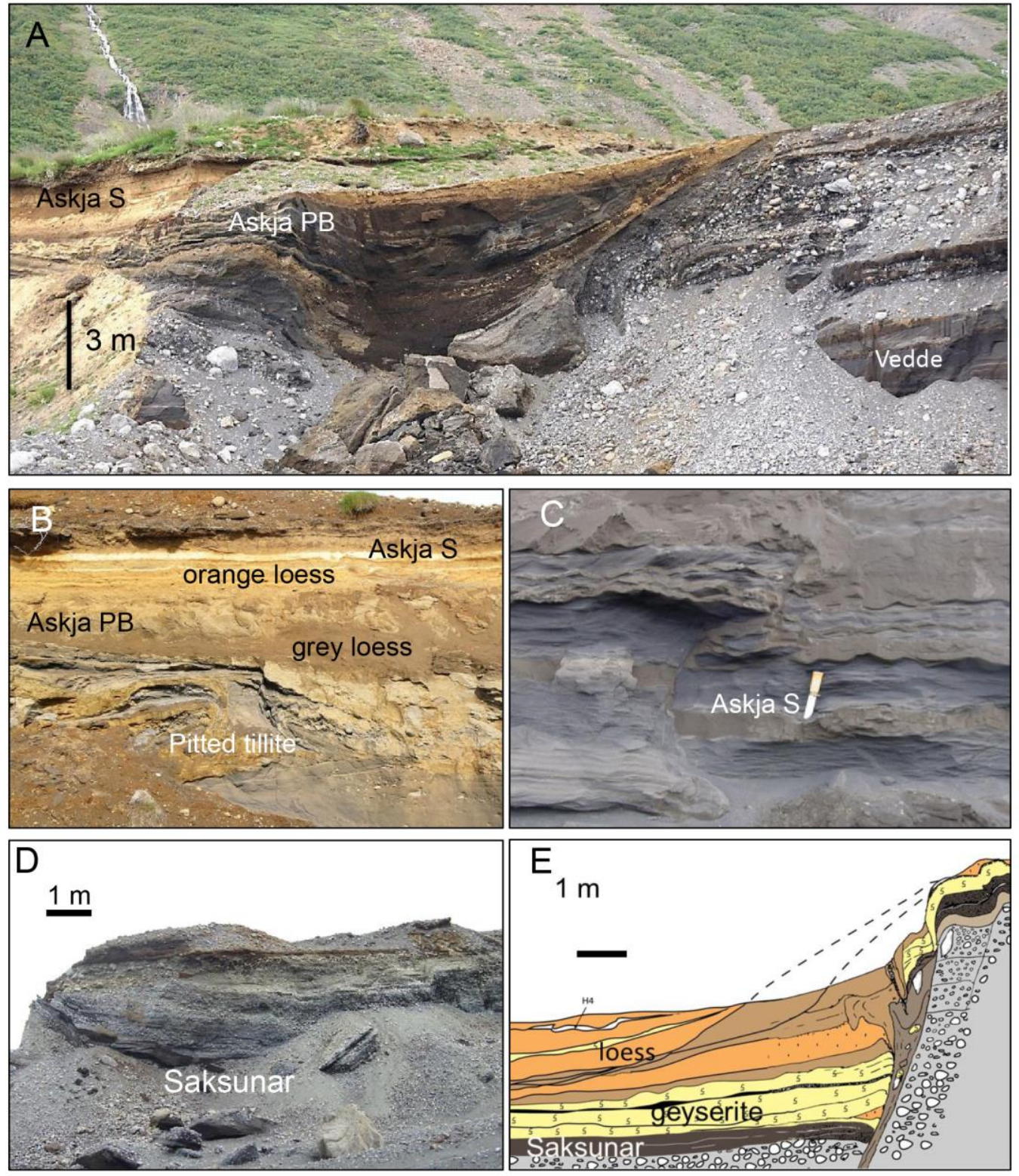


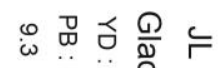

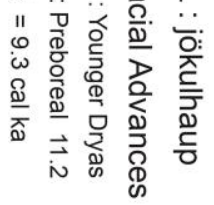
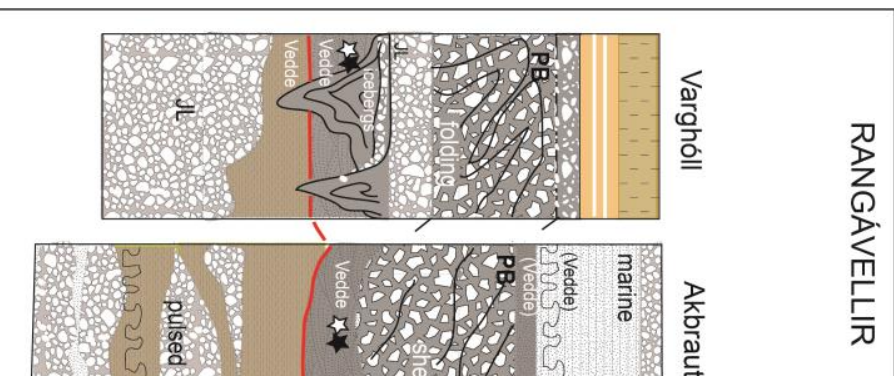

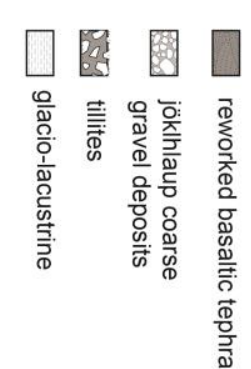

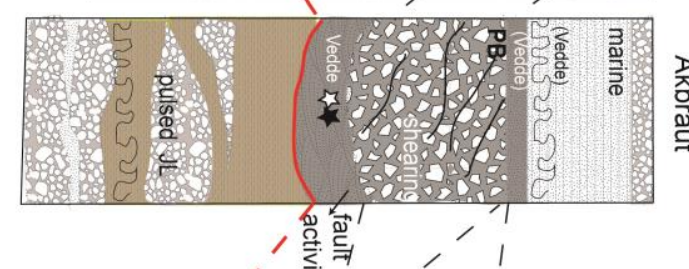

学

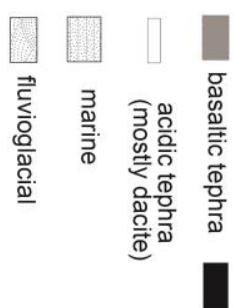

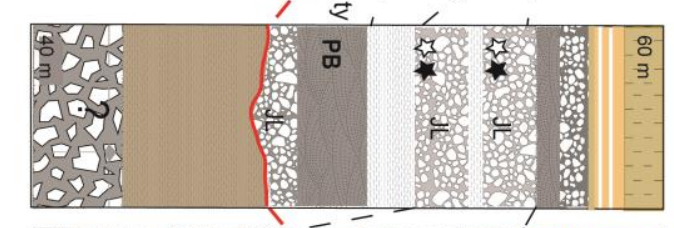

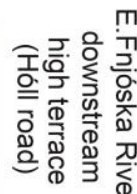

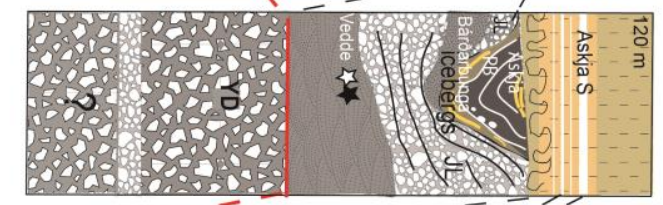

()
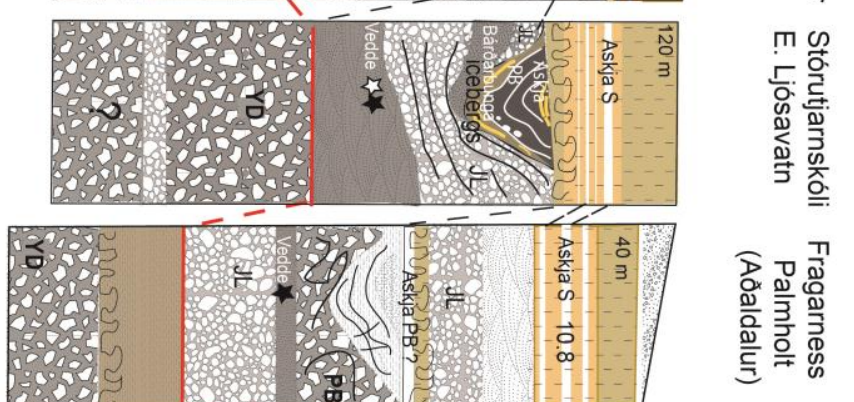

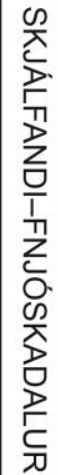
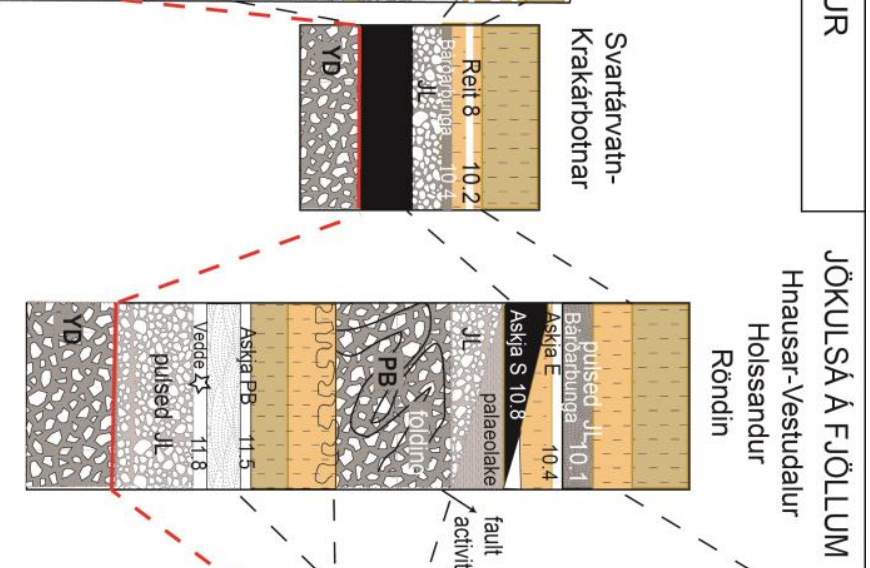

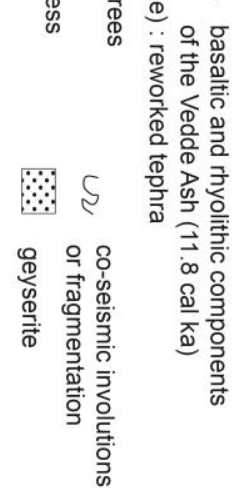

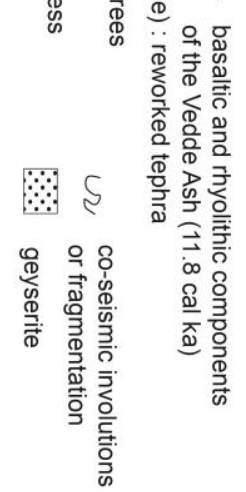

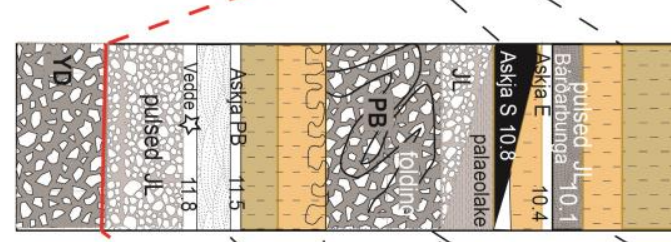

总

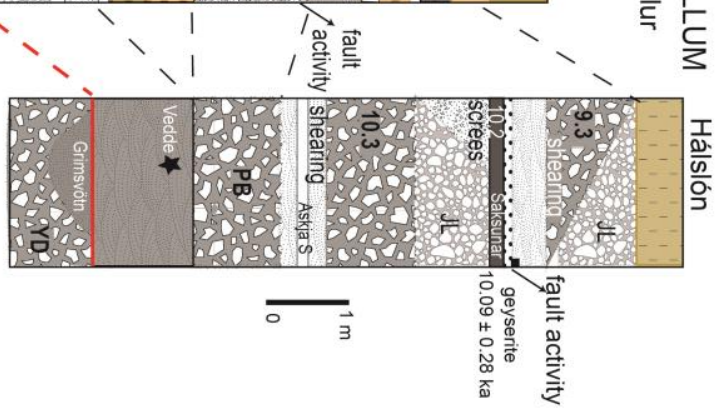



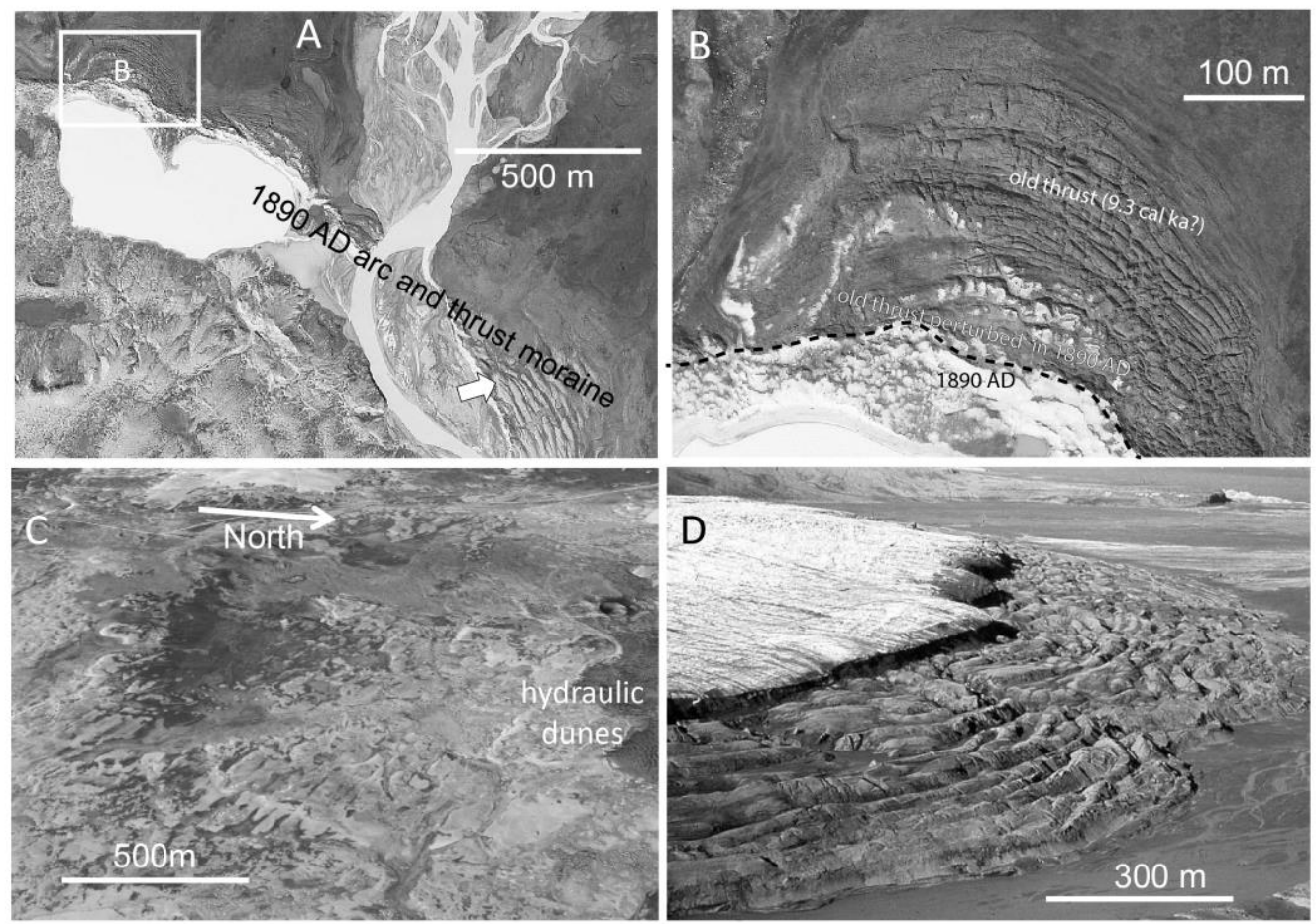

1421

1422 Fig.11
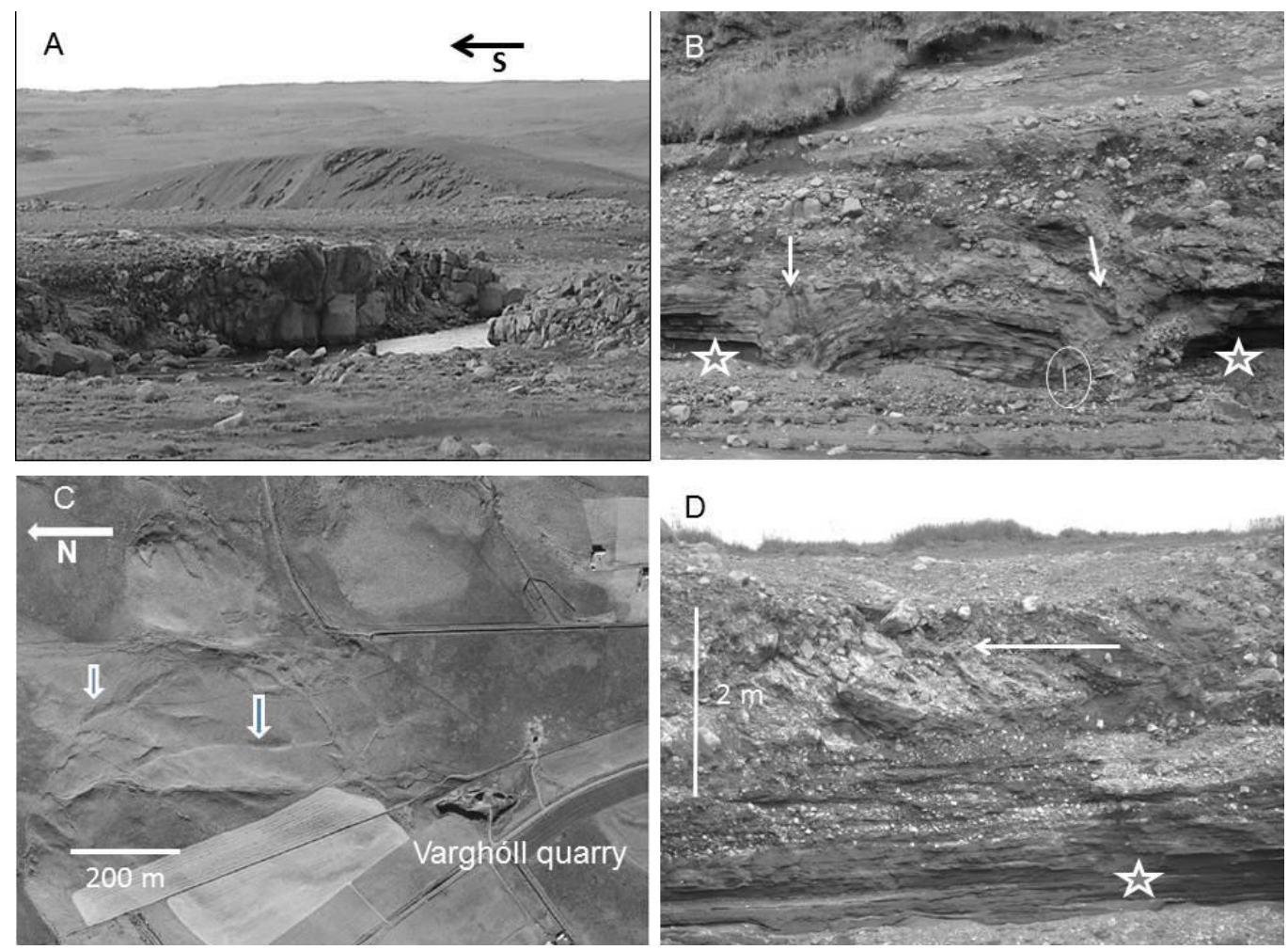

Fig.12 


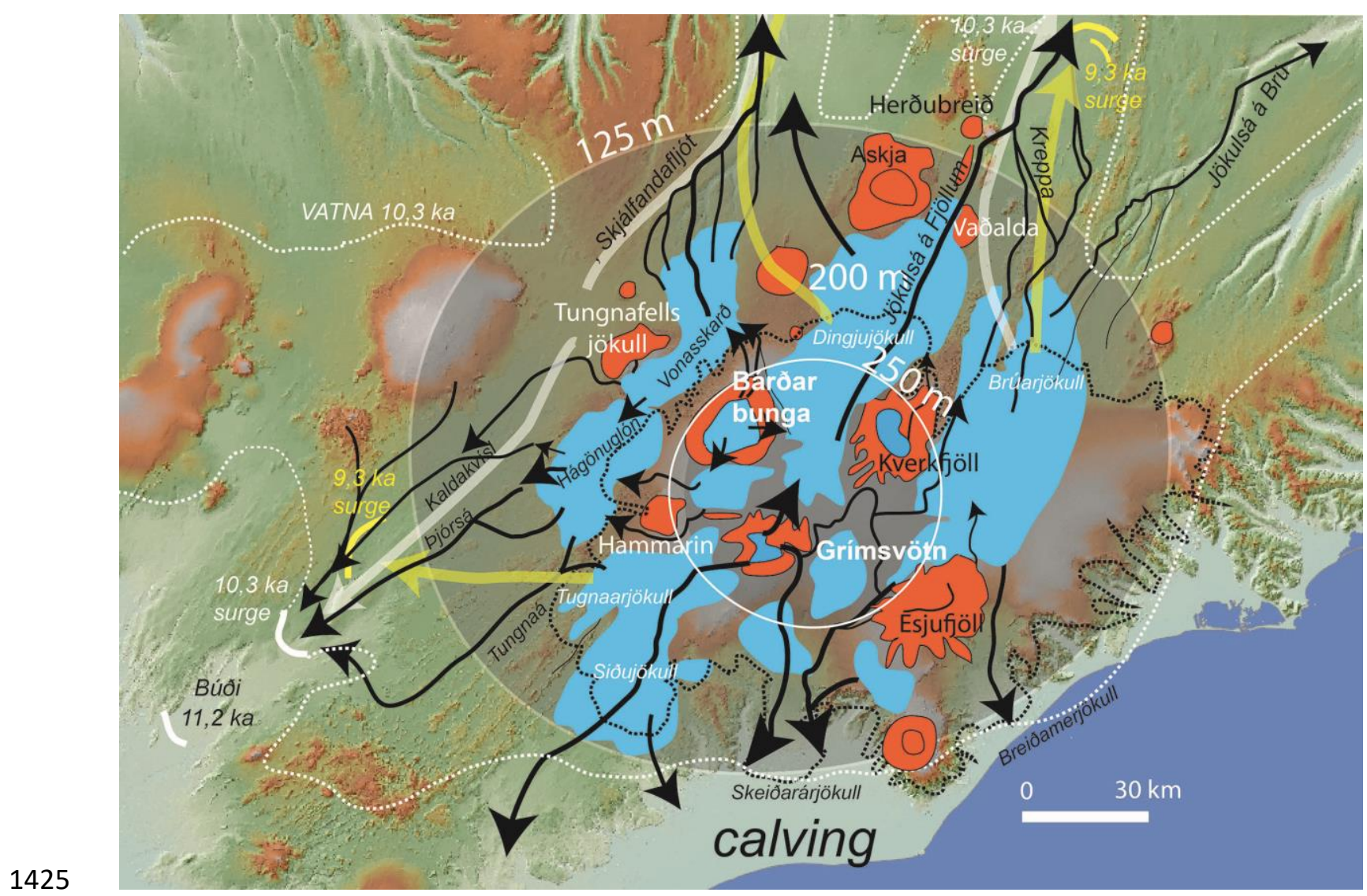

1426 Fig.13 